Pamphlet Series

No. 41

Michael Ainley 
INTERNATIONAL MONETARY FUND PAMPHLET SERIES

(All pamphlets have been published in English. French, and Spanish. unless otherwise stated)

*1. Introduction to the Fund, by J. Keith Horsefield. First edition. 1964. Second edition. 1965. Second edition also in German.

*2. The International Monetary Fund: Its Form and Functions, by J. Marcus Fleming. 1964. In English only.

3. The International Monetary Fund and Private Business Transactions: Some Legal Effects of the Articles of Agreement, by Joseph Gold. 1965.

4. The International Monetary Fund and International Law: An Introduction. by Joseph Gold. 1965.

*5. The Financial Structure of the Fund, by Rudolf Kroc. First edition. 1965. Second edition, 1967.

6. Maintenance of the Gold Value of the Fund's Assets, by Joseph Gold. First edition. 1965. Second edition, 1971 .

7. The Fund and Non-Member States: Some Legal Effects, by Joseph Gold. 1966.

8. The Cuban Insurance Cases and the Articles of the Fund, by Joseph Gold. 1966.

9. Balance of Payments: Its Meaning and Uses, by Poul Høst-Madsen. 1967.

*10. Balance of Payments Concepts and Definitions. First edition, 1968. Second edition. 1969.

11. Interpretation by the Fund, by Joseph Gold. 1968.

12. The Reform of the Fund, by Joseph Gold. 1969.

13. Special Drawing Rights, by Joseph Gold. First edition. 1969. Second edition, with subtitle Character and Use, 1970.

14. The Fund's Concepts of Convertibility, by Joseph Gold. 1971.

15. Special Drawing Rights: The Role of Language. by Joseph Gold. 1971.

16. Some Reflections on the Nature of Special Drawing Rights, by J.J. Polak. 1971.

17. Operations and Transactions in SDRs: The First Basic Period, by Walter Habermeier. 1973.

18. Valuation and Rate of Interest of the SDR, by J.J. Polak. 1974.

19. Floating Currencies, Gold, and SDRs: Some Recent Legal Developments, by Joseph Gold. 1976. Also in German.

20. Voting Majorities in the Fund: Effects of Second Amendment of the Articles, by Joseph Gold. 1977.

21. International Capital Movements Under the Law of the International Monetary Fund, by Joseph Gold. 1977.

22. Floating Currencies, SDRs, and Gold: Further Legal Developments, by Joseph Gold. 1977. Concluding section also in German.

23. Use, Conversion, and Exchange of Currency Under the Second Amendment of the Fund's Articles, by Joseph Gold. 1978.

(Continued on inside back cover) 


\title{
The General Arrangements to Borrow
}

\author{
Michael Ainley
}

INTERNATIONAL MONETARY FUND

Washington, D.C.

1984

CInternational Monetary Fund. Not for Redistribution 
International Standard Serial Number: ISSN 0538-8759

Reprinted March 1986

Reprinted March 1995

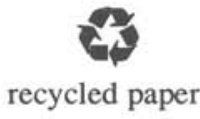

Please send orders to:

International Monetary Fund, Publication Services

700 19th Street, N.W., Washington, D.C. 20431, U.S.A.

Tel.: (202) 623-7430 Telefax: (202) 623-7201

Internet: publications@imf.org

CInternational Monetary Fund. Not for Redistribution 


\section{CONTENTS}

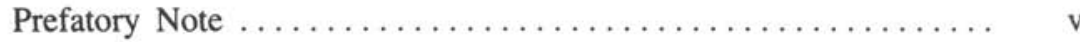

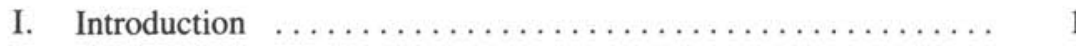

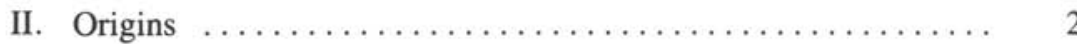

1. Short-Term Expedients $\ldots \ldots \ldots \ldots \ldots \ldots \ldots \ldots \ldots 2$

2. The Fund's Response $\ldots \ldots \ldots \ldots \ldots \ldots \ldots \ldots \ldots 4$

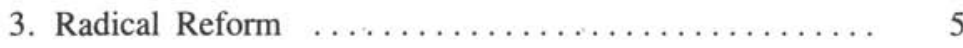

4. The General Arrangements to Borrow (GAB) ...... 6

III. Main Provisions, $1962-82 \ldots \ldots \ldots \ldots \ldots \ldots \ldots \ldots \ldots \ldots . \ldots \ldots$

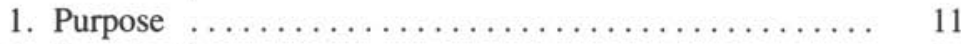

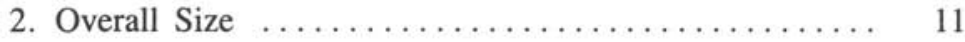

3. Individual Credit Lines $\ldots \ldots \ldots \ldots \ldots \ldots \ldots \ldots \ldots 12$

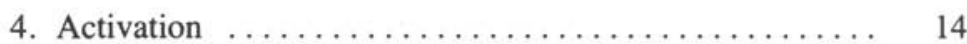

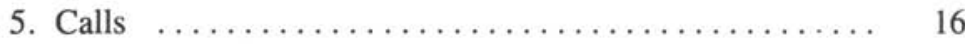

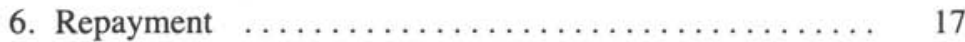

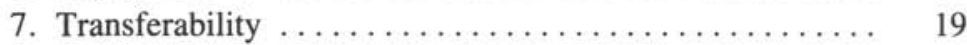

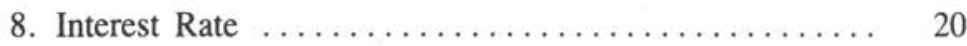

9. Renewal and Modifications ................ 22

10. Association of Switzerland ................ 23

11. Increase in Japan's Credit Line ............... 24

IV. The GAB in Operation, $1962-82 \ldots \ldots \ldots \ldots \ldots \ldots \ldots .25$

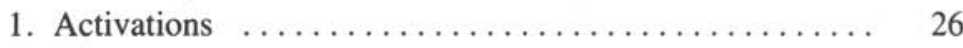

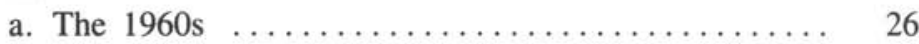

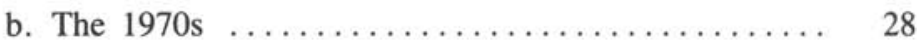

2. Principles and Practices ................... 30

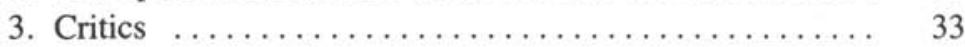

4. Reforms Postponed .................... 34

V. Reform, $1982-83$........................ 39

1. The Reason Why ...................... 39

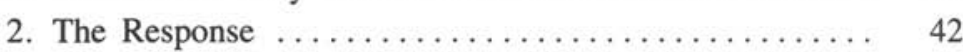

3. The Changes $\ldots \ldots \ldots \ldots \ldots \ldots \ldots \ldots \ldots \ldots \ldots \ldots, 45$

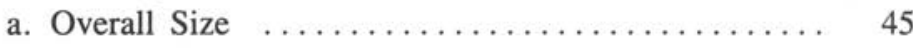

b. Individual Credit Lines $\ldots \ldots \ldots \ldots \ldots \ldots \ldots 46$

c. Participation of Switzerland ............. 47 
d. Associated Borrowing Arrangements ........... 47

e. Associated Arrangement with Saudi Arabia ....... 48

\begin{tabular}{ll} 
f. Use of the GAB for the Benefit of Nonparticipants & 49 \\
\hline
\end{tabular}

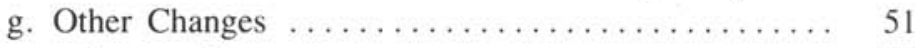

Interest Rate ....................... 51

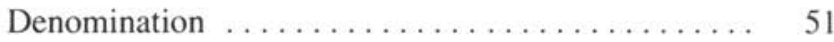

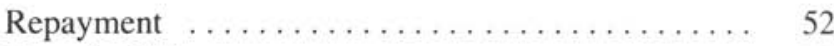

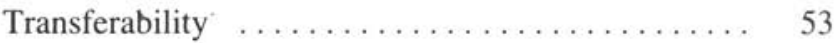

Tidying Up $\ldots \ldots \ldots \ldots \ldots \ldots \ldots \ldots \ldots \ldots \ldots \ldots \ldots \ldots \ldots$

$\underline{\text { h. Period of Renewal and Review ............. } 54}$

VI. A Look Ahead ............................... 54

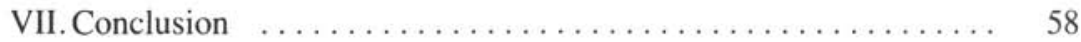

Appendices

I. General Arrangements to Borrow: Original Decision ........ 61

II. The Baumgartner Letter $\ldots \ldots \ldots \ldots \ldots \ldots \ldots \ldots \ldots \ldots . \ldots \ldots$

III. General Arrangements to Borrow: Revised Text $\ldots \ldots \ldots \ldots 70$

IV. Borrowing Arrangement with Saudi Arabia in Association with the General Arrangements to Borrow ............. 80

V. Distribution of Calls on the General Arrangements to Borrow

$\underline{\text { Tables }}$

1. GAB: Individual Credit Arrangements, $1962 \ldots \ldots \ldots \ldots 13$

2. Fund Financing Involving the GAB, 1964-70 $\ldots \ldots \ldots \ldots 27$

3. Fund Financing Involving the GAB, 1977-78 ........ 29

4. Enlarged GAB: Individual Credit Arrangements . ....... 46

\begin{tabular}{llll}
\hline 5. Borrowing by the Fund Under the GAB, 1964-70 $\ldots \ldots \ldots$ & 85 \\
\hline 6.
\end{tabular}

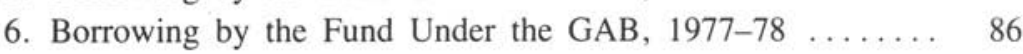




\section{PREFATORY NOTE}

This pamphlet examines the role of the Fund's first and longest-lasting borrowing arrangements, the General Arrangements to Borrow (GAB), from their inception in 1961-62 to their fundamental reform and enlargement in 1983. They have played an important, but controversial, part in the Fund's history, and will almost certainly do so in its future.

The author has been involved in Fund issues since 1974, initially at the Bank of England and, since 1980, on secondment and leave of absence at the Fund as Assistant, first to the Executive Director for the United Kingdom and then to the Executive Director for Saudi Arabia. He was present at many of the discussions in 1982-83 leading to the reform and enlargement of the $\mathrm{GAB}$ and the associated borrowing arrangement with Saudi Arabia.

The author is indebted to several colleagues in the Fund and member governments for advice, comments, and assistance. He is particularly grateful to Sir Joseph Gold, Yusuf A. Nimatallah, J.J. Polak, and David Williams for sharing their first-hand knowledge and experience of the issues and events discussed in the pamphlet. He would also like to thank Margaret Garritsen de Vries for her encouragement and permission to draw on her forthcoming history of the Fund (1972-78); Neil Ainley and John Anson for their informed guidance; and Dominique Berthet for his technical help. He is also grateful to Paul Gleason (editor), Cecilia Poppe and Bruce Barrington (secretaries), and the Composition Unit of the Graphics Section.

The pamphlet was completed in September 1984 and does not take account of developments since then. The opinions expressed, and any errors or omissions, are those of the author and should not be construed as those of the International Monetary Fund.

September 1984 
This page intentionally left blank 


\section{The General Arrangements to Borrow}

\section{Introduction}

The General Arrangements to Borrow (GAB) were established in 1962 by the Fund in cooperation with eight of the major industrial countries and the central banks of two others. ${ }^{1}$. They were the first credit lines arranged by the Fund to supplement its ordinary, quota-based resources. They initially totaled the equivalent of US\$6 billion, which was then the largest single loan agreement ever entered into. ${ }^{2}$

The General Arrangements were a product of the times. They were designed to help the Fund deal with growing strains in the par value system caused by the underlying balance of payments problems of the two major reserve centers, the United States and the United Kingdom, and by the greater freedom for short-term capital movements, following the return to external convertibility in Europe and Japan. They were not automatic credit lines. They could be drawn on only with the consent of the participants and only when supplementary resources were needed to "forestall or cope with an impairment of the international monetary system" in the (then) "new conditions" of widespread convertibility. ${ }^{3}$ They could be used by the Fund only to finance transactions with the participants.

The General Arrangements were strengthened by the association of Switzerland, a nonmember of the Fund, in 1964. They have been activated on nine occasions, the first of which was in 1964, and the most recent in 1978. The General Arrangements have been used to assist in financing large drawings on the Fund by the United Kingdom, France, Italy, and the United States. They have been renewed five times, most recently in 1983, for a further five years.

\footnotetext{
${ }^{1}$ United States, the United Kingdom, the Deutsche Bundesbank, France, Japan, Italy, Canada, Netherlands, Belgium, and the Sveriges Riksbank.

${ }^{2}$ Gold (1979), Chap. 12, pp. 446-68.

${ }^{3}$ See Preamble to Executive Board Decision No. 1289-(62/1), January 5, 1962, as amended, in Selected Decisions of the International Monetary Fund and Selected Documents, Tenth Issue (April 30, 1983) (hereinafter referred to as Selected Decisions, 10 th (1983)), p. 117.
} 
However, with the important exception of the increase in Japan's credit line in 1976, the General Arrangements have remained substantially unchanged from their inception . . . until now. Major changes were agreed in late 1982 and early 1983 and took effect in December 1983. The General Arrangements have been enlarged, and their scope has been broadened. Their importance as a second, if not a first, line of support for the Fund has been significantly increased.

This pamphlet reviews the origins, purpose, and provisions of the General Arrangements. It examines their role in the 1960s and in the 1970s. It then assesses the reasons for the 1982-83 reforms and analyzes the main changes. The pamphlet concludes with a brief look ahead to the role which the revised General Arrangements could play in the mid1980s.

\section{Origins}

The General Arrangements were established against a background of widespread, and growing, concern about the adequacy of official sources of international liquidity, in general, and the disruptive effects of shortterm capital movements, in particular. The return to external convertibility of the major European currencies in 1958, and of the Japanese yen in 1961, followed by the elimination of exchange restrictions and the relaxation of capital controls in these countries, had a dramatic effect on the international trade and payments system established at Bretton Woods. These developments created the conditions for larger and more frequent transfers of short-term capital between countries, in response not simply to interest rate differentials but also to anticipated changes in par values and other speculative factors.

The two major reserve-currency countries, the United States and the United Kingdom, were particularly exposed to such transfers because of their balance of payments problems. Sterling was subject to periodic pressure in the exchange markets; and the growing payments deficits of the United States were also exacerbated by large capital outflows accompanied, at times, by flights from dollars into gold.

\section{Short-Term Expedients}

The increasing volatility in the exchange markets, continuing large payments deficits in the United States, and the accumulation of sizable 
official and private holdings of dollars prompted a series of responses by the major industrial countries in 1961-62. In March 1961, for example, immediately after large revaluations of the deutsche mark and the guilder, the central banks of the major European countries, meeting at the Bank for International Settlements (BIS) in Basle, agreed to cooperate closely in the foreign exchange markets to discourage speculation and to minimize the repercussions of speculative movements on their foreign exchange reserves. More specifically, the central banks agreed to hold each other's currencies to a greater extent than before, instead of converting them immediately into gold or dollars, and to provide short-term loans to assist each other when their currencies were in difficulty because of speculation.

The Basle Agreement, as it was called, was followed, in February 1962, by the establishment of systematic swap facilities at the U.S. Federal Reserve with the central banks of the United Kingdom, Canada, the Federal Republic of Germany, Italy, Japan, Switzerland, France, the Netherlands, Austria, Belgium, Sweden, and the BIS. These swaps, which totaled more than US $\$ 2$ billion by February 1964, were heavily used throughout the 1960 s, particularly by the United Kingdom, as a reversible, short-term defense against exchange market disturbances. At the same time, the major central banks, led by the Federal Reserve, moved to coordinate their policies on short-term interest rates and on intervention, in forward as well as spot markets, with the aim of preventing, or at least reducing, speculative capital movements.

Speculation at this time was not confined to currencies but included gold, the second main source (with the dollar) of official liquidity and reserves under the gold exchange standard. Intense speculation regarding a possible rise in the official price of gold, then US $\$ 35$ an ounce, led, in October 1961, to the creation of the London "Gold Pool" by the major central banks. Under this arrangement, the central banks of Belgium, France, the Federal Republic of Germany, Italy, the Netherlands, Switzerland, and the United States agreed, informally, in cases of need, to share with the Bank of England the burden of intervening in the London gold market to keep the market price of gold at, or close to, the official price. This informal sales consortium, which provided gold to the market for the first time in November 1961, remained in operation until March 1968, when a two-tier gold market, separating the free market from the official market, was introduced.

These arrangements were ad hoc financing mechanisms to deal with 
short-term crises. They did not address the underlying problems in the Bretton Woods system, problems which stemmed from the heavy reliance on the dollar as the main source of international liquidity; from the reluctance of countries to change par values until the last minute; and from the delays in adjusting domestic policies, particularly among countries with persistent deficits. This is where the Fund, and ultimately the GAB, came in. It was not without significance that the Basle Agreement of March 1961 concluded that

These procedures [for closer exchange market cooperation] will be temporary, pending the evolution of more permanent techniques for dealing with the problems of international financial disequilibria, particularly short-term capital movements within the framework of, or through reform of, the International Monetary Fund. ${ }^{4}$

\section{The Fund's Response}

Before 1961, the Fund's response to the more rapid growth in world trade and to the problem of large short-term capital movements was twofold. First, a large general increase in quotas (50 percent) was agreed in 1959, with provision for special increases for countries like Canada, the Federal Republic of Germany, and Japan to reflect their growing economic importance. Second, the Fund allowed members access to its resources on a then unprecedented scale. The period 1960-61 was, for example, one of the most active in the Fund's history. Twenty-four standby arrangements were approved for a total of approximately US $\$ 1,500$ million, including one of US\$500 million for the United Kingdom. ${ }^{5}$

However, despite a consensus at the Fund's Annual Meeting in 1960 that there was "no lack of international liquidity," 6 it became increasingly apparent that the Fund should do more. The continuing large shifts in the balance of payments positions of the major countries were expected to lead to even greater demands on the Fund. But, even after the quota increase in 1959, the industrial countries in strong external positions had relatively small Fund quotas. The Fund's holdings of their "lendable" currencies were low. By contrast, the external positions of the United

\footnotetext{
${ }^{4}$ Horsefield and others (1969), Vol. 1, p. 483.

${ }^{5}$ Ibid., p. 486.

${ }^{6}$ Ibid., p. 492. The quotation is taken from Per Jacobsson's concluding remarks delivered at the Fund's Fifteenth Annual Meeting on September 30, 1960. See International Monetary Fund, Summary Proceedings of the Fifteenth Annual Meeting of the Board of Governors (September 1960), p. 125.
} 
States and the United Kingdom, the two reserve currency countries with the largest quotas, were not strong; and these two countries were the most vulnerable to capital outflows.

The obvious solution of a further increase in Fund quotas, with selective increases for "strong" countries, was considered impracticable so soon after the 1959 increases, and because it would have been a further drain on members' reserves. There were, therefore, doubts, both inside and outside the Fund, whether its resources were sufficient to deal with the potential problems of the two reserve centers. These doubts were especially marked with regard to the United States, given its very large quota and the possibility that its drawings could have limited the Fund's ability to assist other members in difficulty. Indeed, the February 1961 statement by President Kennedy to Congress that the United States might wish to use the Fund's resources was the most important immediate reason for the Fund's decision to supplement its currency holdings with a borrowing arrangement. $^{7}$

\section{Radical Reform}

The General Arrangements were thus a response to the needs of the time. There was, however, no shortage of proposals designed to remedy the perceived defects in the international monetary system. The more radical ideas came from outside the Fund. They included the Triffin Plan, under which the Fund would become an international central bank for central banks authorized to create money in accordance with international liquidity requirements; and the Stamp Plan, under which the Fund would create a new form of credit certificates which could be used to meet both the needs of industrial countries for additional liquidity and of developing countries for additional foreign capital. Economists such as Roy Harrod and Jacques Rueff went further, arguing that the shortage of international liquidity could be solved by doubling or even tripling the official price of gold. Milton Friedman proposed abandoning the par value system and replacing it with freely flexible exchange rates that could reduce, if not eliminate, the need for central banks to hold reserves. ${ }^{8}$

Other less radical plans, such as those of Edward Bernstein, looked ahead to broadening the base of the gold exchange standard through a

\footnotetext{
${ }^{7}$ Gold (1977).

${ }^{8}$ de Vries (1976), Vol. 1, Chap. 1, pp. 11-24.
} 
system of "multiple reserve currencies" in addition to dollars and sterling. The Fund staff also explored various possibilities, including that of inviting deposits of gold or currencies from surplus members which could be used, if necessary, to replenish the Fund's holdings of particular currencies. $^{9}$

Although none of these ideas was adopted, and many were too extreme for the financially orthodox countries, they marked the beginning of the long debate on the adequacy of international liquidity, and of the Fund's lending facilities, which continued throughout the 1960s. It culminated in the creation of the special drawing rights facility within the Fund in 1969.

\section{The GAB}

The General Arrangements themselves were something of a halfway house between the temporary financing expedients established by central banks and the wholesale reform proposals outlined earlier. If they were part of the "ingenious devices for creation of international liquidity" 10 devised to keep the system going, they were also something more. The General Arrangements were within the Fund's framework, and therefore at the center of the system; and they provided support over the medium, and not just over the short, term.

The General Arrangements were created after extensive preparatory work by senior Fund staff members, which included a number of informal discussions with national officials. They were first put forward by Per Jacobsson, then Managing Director, in February 1961 as part of a pragmatic package of measures aimed at strengthening the Fund's resources in the aftermath of convertibility.

The package had three related elements. The first was clarification of the principle that members could, in certain circumstances, use Fund resources to meet balance of payments deficits that went beyond the current account and were attributable, in whole or in part, to capital transfers. ${ }^{11}$ Clarification was needed because of a 1946 interpretation of the Fund's Articles of Agreement by the Executive Board that limited the use of the Fund's resources to the financing of deficits "on current account

\footnotetext{
${ }^{9}$ Horsefield (1969), Vol. 1, Chap. 19, pp. 495-522.

${ }^{10}$ Halm (1971), p. 12.

"For a comprehensive account of this issue, see Gold (1977).
} 
for monetary stabilization operations." 12 This interpretation, which reflected U.S. concerns after World War II that Fund resources not be wasted in financing capital flight from members maintaining overvalued currencies, was overly restrictive. It ignored the provisions of the Articles, and Article VI in particular, which allowed the Fund to finance capital transfers, for example, where a capital outflow was not deemed to be "large or sustained." Although the interpretation had been virtually forgotten, the position had to be clarified before the Fund could establish a borrowing arrangement specifically designed to deal with problems relating to short-term capital movements.

Accordingly, the Executive Board re-examined the 1946 interpretation and decided, in July 1961, that it did "not preclude the use of the Fund's resources for capital transfers in accordance with the provisions of the Articles, including Article VI."13 This did not mean that the Fund would allow its resources to be used irrespective of a member's circumstances or of the volume of a capital outflow. But it gave the Fund flexibility in deciding what constituted "large or sustained" capital outflows under Article VI; and it removed a potential obstacle in the way of setting up the GAB.

The second element of the package involved the establishment of new guidelines for the selection of currencies to be used in financing members' transactions with the Fund. Prior to 1961, little use had been made of any currency except the U.S. dollar in drawings on the Fund. Even when the currencies of the major European countries became convertible, in the Fund sense, under Article VIII in February 1961, it did not automatically follow that these currencies would be used in Fund drawings. Most members kept their foreign exchange reserves in U.S. dollars, pounds sterling, or French francs and preferred to draw one of these currencies if they were in balance of payments difficulties.

The new guidelines, which were adopted in July 1962 after extensive discussion by the Executive Board, ensured that drawings from, and repayments to, the Fund would take place in a broad range of currencies. The Fund would select currencies for drawings, through quarterly

\footnotetext{
${ }^{12}$ Interpretation, Pursuant to Executive Board Decision No. 71-2, September 26, 1946 , in Selected Decisions, 10th (1983), p. 18.

${ }^{13}$ Executive Board Decision No. 1238-(61/43), July 28, 1961, in Selected Decisions, 10th (1983), p.18.
} 
operational budgets, from a list of countries in strong balance of payments and reserve positions whose currencies could be converted into the currency directly needed by the drawing member. Very broadly, drawings would be allocated among these countries in proportion to the size of their gold and foreign exchange reserves. The guidelines reflected the important principle that reserves should flow, through the Fund, from countries with strong balances of payments to countries with weak ones. ${ }^{14}$

The third element of the package was the proposal that the Fund establish a mechanism ahead of need under which it could borrow currencies to finance large drawings. The idea of a comprehensive borrowing arrangement had the advantage over more radical schemes in that it was within the limits of what was politically feasible, although only just, and did not require an amendment of the Fund's Articles of Agreement. It could be, and was, implemented quickly under the replenishment provisions of Article VII. ${ }^{15}$

The list of participants was agreed within a few months. It was based on a number of economic and financial criteria drawn up by the Fund staff. These included quota size, level of reserves, actual or prospective balance of payments surpluses, and the Fund's likely needs for particular currencies. The list had been more or less finalized by August 1961, when the Fund used the currencies of the eventual participants to finance a US $\$ 1,500$ million drawing by the United Kingdom. The choice of the ten GAB participants led, significantly, to the formation of the Group of Ten, which quickly developed a wider role in examining and coordinating positions on international monetary problems in the 1960s. It also determined, a little later, the composition of the Organization for

\footnotetext{
${ }^{14}$ For a detailed account of the guidelines, see Horsefield and others (1969), Vol. 2, Chap. 19, pp. 428-67.

${ }^{15}$ Article VII, Section 2 of the original Articles stated, inter alia, that:

The Fund may, if it deems such action appropriate to replenish its holdings of any member's currency,...

(i) Propose to the member that, on terms and conditions agreed between the Fund and the member, the latter lend its currency to the Fund or that, with the approval of the member, the Fund borrow such currency from some other source either within or outside the territories of the member, but no member shall be under any obligation to make such loans to the Fund or to approve the borrowing of its currency by the Fund from any other source.
} 
Economic Cooperation and Development's (OECD) influential Working Party 3 (WP3) on economic and financial issues.

In practice, drawing up a list of participants was not quite so straightforward. France had to be persuaded that the Fund really needed additional resources at that time. Japan was almost left out, because of temporary balance of payments difficulties, and was included only on the "strongest advice" of Jacobsson. ${ }^{16}$ Canada and Sweden had doubts, as late as November 1961, whether they should participate at all. Austria, which the Fund staff had viewed as a possible participant, was not included.

Inevitably, the final version was a compromise, political as well as financial, agreed after "much diplomacy and involved negotiations." ${ }^{17}$ In the process, Jacobsson's idea of a global fund which would be available to finance drawings on the Fund by all members was lost. Some of the European countries invited to participate were critical, and France in particular, according to Jacobsson, regarded the proposal as "a trick of the Anglo-Saxon nations." 18 These countries were especially concerned about the persistent balance of payments weaknesses of the United States and, to a lesser extent, of the United Kingdom. They wanted to ensure that any additional resources made available to the Fund would be on-lent on conditions no less stringent than those applicable to ordinary drawings. They insisted on having real control over the use of the borrowed funds, and this was subsequently reflected in the voting provisions of the Baumgartner letter. ${ }^{19}$ Their bargaining position was strong, since they did not expect to have to use the Fund's resources in the foreseeable future.

In contrast, countries like the United States and the United Kingdom, which sympathized with Jacobsson's plan, were in a weaker bargaining position, since they did expect to draw on the Fund and wanted its resources increased. The United States wanted to get some kind of Fund borrowing arrangement in place and was therefore prepared to consider alternative proposals more acceptable to the European critics. This was reflected in a Franco-U.S. proposal, in November 1961, for a Special

\footnotetext{
${ }^{16}$ Jacobsson (1979), p. 382.

${ }^{17}$ Ibid., p. 358 .

${ }^{18}$ Ibid., p. 360. The quotation is taken from an entry in Per Jacobsson's diary dated January 27, 1961. It describes Jacobsson's estimation of the view of Jean de Largentaye, Executive Director for France, concerning replenishment of the Fund's resources by borrowing.

${ }^{19}$ See Section III.
} 
Resources Facility within the Fund. Under this scheme, the decision to allow use of Fund resources, if borrowed funds were involved, would have been made by the lending countries, and not by the Fund. Similarly, the choice between using Fund resources or borrowed resources would have been made by the borrowing country, not the Fund. The proposal was, understandably, rejected by Jacobsson, since it would have impaired the Fund's authority and was inconsistent with the Articles of Agreement; but it demonstrated very clearly the limits to cooperation between the major industrial countries and the Fund.

The General Arrangements to Borrow, which were finally agreed by the Group of Ten in December 1961 and approved by the Fund's Executive Board in January 1962, were, therefore, different from Jacobsson's original proposal. The credit lines established were highly contingent commitments. They could not be drawn on automatically by the Fund. They could be used only in exceptional circumstances with the concurrence of the Group of Ten, collectively, and the individual consent of prospective creditors.

Equally significant, the credit lines could be called on only to finance drawings on the Fund by the participants. In other words, they were for the exclusive use of the Group of Ten. In addition, the amount available to the Fund at any one time was always less than the overall total of US $\$ 6$ billion. At each activation, the credit line of the prospective GAB beneficiary had to be deducted from the total; and the amounts which could be drawn from the other credit lines depended on the balance of payments and reserve positions of the participants.

The General Arrangements also differed from other Fund decisions, and subsequent Fund borrowing arrangements, in two other important ways. First, they included a provision for periodic renewals of the credit lines. They have since become a more or less permanent arrangement, in contrast to the Fund's temporary borrowing, for more specific purposes, under the 1974-75 oil facilities, the 1977 supplementary financing facility, and-more recently - the enlarged access policy. Second, important amendments to the GAB required not only a decision by the Executive Board but also the agreement of all ten original participants. It is this last provision which helps to explain the GAB's remarkable resistance to change over the past 20 years. 


\section{Main Provisions, 1962-82}

\section{Purpose}

The General Arrangements were designed to give the Fund adequate resources to impress the exchange markets and deter speculation, as well as to deal with exchange market crises. They allowed the Fund to borrow from those of its members among whom short-term capital movements were likely to occur, and thus to enlist the support of countries experiencing capital inflows in assisting a country suffering from capital outflows. ${ }^{20}$ They were an extra line of defense, incorporated within the Fund's ordinary lending procedures, alongside participants' reserves and normal Fund drawing rights.

It was, however, a conditional line of defense. Under the Fund decision which established the GAB, each participant reserved the right to decide whether or not to lend to the Fund - the only borrowing agreement of the Fund where this is so. However, to counterbalance this, the participants agreed "in a spirit of broad and willing cooperation" to stand ready to lend their currencies to the Fund, up to specified amounts, when supplementary resources were needed "to forestall or cope with an impairment of the international monetary system" in the new conditions of widespread convertibility. ${ }^{21}$ It was also possible, not under the GAB decision but under the consultation procedures established by the participants themselves, for the participants to decide, collectively (by vote), to meet a proposed call by the Fund, a decision which would normally oblige individual participants to lend. ${ }^{22}$

\section{Overall Size}

The credit arrangements, which were denominated in the national currencies of participants, originally totaled the equivalent of US\$6 billion. ${ }^{23}$ This figure was regarded as sufficient to cover concurrent use of

\footnotetext{
${ }^{20}$ Gold (1979), Chap. 12, pp. 446-68.

${ }^{21}$ Preamble to Executive Board Decision No. 1289-(62/1), January 5, 1962, as amended, in Selected Decisions, 10th (1983), p. 117.

${ }^{22}$ See subsection 4, "Activation."

${ }^{23}$ Denominating the credit lines in national currencies meant that the gold (later the SDR) value of individual credit lines could, and did, change in response to exchange rate changes. The participants felt that exchange rate changes would reflect shifts in their relative economic positions and, hence, in their ability to provide finance to the Fund. (See Section IV.)
} 
the Fund's resources by the United States and the United Kingdom, then the most likely possibility, or to finance large drawings by the other major industrial countries. It would thus enable the Fund to cope with a large U.S. payments deficit vis-à-vis the continental European countries, or the opposite situation.

More specifically, studies by the Fund staff indicated that the Fund might require some US\$2 billion in dollars, in addition to its holdings of dollars and gold, to meet possible drawings by major industrial countries other than the United States and by developing countries. This was important in determining the amount of the U.S. credit line. The same studies showed a potential need for some US\$3.5-5 billion in currencies, other than the U.S. dollar and pound sterling, to meet a combination of demands from the two reserve centers and the smaller industrial countries. The Fund staff was not, however, able to estimate the precise extent of the Fund's likely need for pounds sterling. The total of US\$6 billion, eventually agreed, was within the range suggested by these calculations.

\section{Individual Credit Lines}

The credit lines established for individual participants are shown in Table 1 .

The main economic rationale for country shares was the participants' gold and foreign exchange reserves, which were considered a more appropriate measure, at least in the short run, of their ability to make resources available than were Fund quotas. This rationale was consistent with the new guidelines, then under discussion at the Fund, for selecting currencies to finance transactions with members, ${ }^{24}$ and also with the view that lending to the Fund was a matter of changing the composition of participants' reserves.

The amounts for the nine participants other than the United Kingdom were based, very broadly, on a similar percentage ( 15 percent on average) of their reserves in late 1961. The amount for the United Kingdom, however, while not out of line with its Fund quota, constituted a considerably larger percentage of its reserves ( 30 percent). This reflected, in part, the low level of U.K. reserves in relation to the country's economic size and also the importance of the pound sterling in world trade and payments at the time. The amount for the United States, one third of

\footnotetext{
${ }^{24}$ See Section II.
} 
TABle 1. GAB: Individual Credit ARRAngements, 1962

\begin{tabular}{|c|c|c|c|}
\hline Participant & $\begin{array}{l}\text { Units of Participant's } \\
\text { Currency }\end{array}$ & $\begin{array}{l}\text { U.S. Dollar } \\
\text { Equivalent } \\
\text { (in millions) }\end{array}$ & $\begin{array}{l}\text { Percentage } \\
\text { Share }\end{array}$ \\
\hline United States & US $\$ 2,000,000,000$ & 2,000 & 33.33 \\
\hline United Kingdom & $£ 357,142,857$ & 1,000 & 16.66 \\
\hline Deutsche Bundesbank ${ }^{1}$ & DM 4,000,000,000 & 1,000 & 16.66 \\
\hline France & NF $2,715,381,428$ & 550 & 9.16 \\
\hline Italy & Lit $343,750,000,000$ & 550 & 9.16 \\
\hline Japan & $¥ 90,000,000,000$ & 250 & 4.16 \\
\hline Canada $^{2}$ & Can $\$ 216,216,000$ & 200 & 3.36 \\
\hline Netherlands & f. $724,000,000$ & 200 & 3.36 \\
\hline Belgium & BF $7,500,000,000$ & 150 & 2.50 \\
\hline Sveriges Riksbank ${ }^{1}$ & SKr $517,320,000$ & 100 & 1.66 \\
\hline Total & & 6,000 & 100.00 \\
\hline
\end{tabular}

${ }^{1}$ Both the Sveriges Riksbank and the Deutsche Bundesbank are empowered, by domestic legislation, to lend to the Fund. They are, therefore, participants in the GAB in their own right and not simply agents of their respective governments. The commitment of Sweden was transferred to the Sveriges Riksbank between December 1961, when the Group of Ten agreed to establish the General Arrangements, and October 1962, when they entered into force.

${ }^{2}$ The amount for Canada, initially fixed at Can $\$ 208,938,000$, was increased before the General Arrangements came into force to maintain the credit line equivalent to US\$200 million after the devaluation of the Canadian dollar in May 1962.

the total, was determined as much by the Fund's potential need for dollars, explained earlier, as by the level of U.S. reserves.

Political factors and straightforward bargaining were just as important. The six participants from the European Community, for example, maintained, successfully, that their combined share should at least equal that of the United States. In the case of the United Kingdom, prestige and the wish to have a large voting power in the separate consultation procedures established among the participants in the $\mathrm{GAB}^{25}$ were perhaps as significant as the Fund's need to meet an exceptional demand for pounds sterling.

\footnotetext{
${ }^{25}$ See subsection 4 .
} 
These political considerations were unavoidable. Similar political considerations were to make it difficult to rearrange the participants' shares at subsequent renewals. The status quo was preferred to potentially controversial changes.

\section{Activation}

The formal procedures for activating the GAB were set out in a January 1962 decision of the Fund's Executive Board. ${ }^{26}$ They were supplemented by separate arrangements, within the Group of Ten, described in a December 1961 letter from Wilfrid Baumgartner (then French Finance Minister and Chairman of the Group of Ten's Finance Ministers) to the other GAB participants. ${ }^{27}$

Under the 1962 decision, the Fund could call on the GAB to finance either a stand-by arrangement or an "exchange transaction" (without a stand-by arrangement) with a participant. ${ }^{28}$ The central, unwritten purpose of the GAB was to cover anticipated large drawings, under standby arrangements, in the credit tranches by one or both of the reserve centers. Such drawings would normally be phased and subject to conditions in line with the Fund's "policies and practices." ${ }^{29}$ The phrase "exchange transaction" also left open the possibility that the General Arrangements could be used to finance more or less automatic drawings, subject to very little or no conditionality, in the gold (now reserve) tranche $e^{30}$ or in the first credit tranche. The Fund's ability to call on the $\mathrm{GAB}$ to finance gold tranche drawings was not specifically discussed when the General Arrangements were established; but the participants subsequently agreed on a procedure for this, in 1968, when they also confirmed that the General Arrangements could be used to cover drawings by all participants (i.e., not just by the two reserve centers). ${ }^{31}$

\footnotetext{
${ }^{26}$ Paragraphs 6 and 7 of Executive Board Decision No. 1289-(62/1), January 5, 1962, as amended, in Selected Decisions, 10th (1983), pp. 119-21.

${ }^{27}$ Ibid., pp. 128-31.

${ }^{28}$ Ibid., pp. 119-21.

${ }^{29}$ Ibid., Paragraph 10 , p. 122.

${ }^{30}$ The gold tranche represented the first part of a member's drawing rights in the Fund, namely the amount by which the Fund's holdings of a member's currency were less than 100 percent of quota. Use of the gold tranche became legally automatic after the First Amendment of the Articles in 1969, and various other improvements in its characteristics have been made since then. It was renamed the reserve tranche following the Second Amendment of the Articles in 1978.

${ }^{31}$ See de Vries (1976), Vol. 1, Chap. 19, pp. 370-72, and Section IV of this pamphlet.
} 
In theory, if not in practice, the Fund proposed and the Group of Ten disposed. Under the formal procedures of the 1962 decision, there were five main steps to be followed once a participant approached the Fund for a drawing. The Managing Director had first to come to a judgment, after consultation, that $\mathrm{GAB}$ resources were needed to forestall or cope with an impairment of the system. He had then to consult with Executive Directors and GAB participants on a possible proposal to activate the GAB. The GAB participants had then to accept the proposal as a group. Each participant then notified the Fund, individually, that it accepted the proposed call under its credit line. Finally, the proposal had to be approved by the Executive Board, which also had to approve the participant's request to use Fund resources. The Executive Board wanted to have the last word, so that the Fund would not be forced to borrow from the GAB simply because the participants had agreed to lend.

The separate arrangements, outlined in Baumgartner's letter, put considerable emphasis on consultations "in a spirit of international cooperation" 32 within the Group of Ten. These consultations were seen as a way of allowing the Group of Ten to assess the Fund's need for supplementary resources, to examine the adjustment policies of the prospective beneficiary, and to agree on the distribution of the Fund's call among themselves.

The participants aim at reaching "unanimous agreement" 33 in their consultations, but there are also fallback provisions in the Baumgartner letter for voting on a proposal by the Managing Director. All participants other than the prospective beneficiary are entitled to vote, even if they are not included in the proposal, since they may be asked to provide substitute amounts at a later date. Abstention is permitted only on the grounds of balance of payments and reserve weakness, which would justify a refusal to lend. A favorable decision requires a two-thirds majority of the participants voting and a three-fifths majority of their votes weighted according to the amount of each participant's credit line.

This voting system differs from that used in the Fund in two important respects. In the Fund, voting power is weighted largely according to members' quotas. Second, in the Fund - unlike the GAB - the beneficiary

\footnotetext{
${ }^{32}$ See Paragraph F of Wilfrid Baumgartner's letter to GAB participants in Selected Decisions, 10th (1983), p. 130.

${ }^{33}$ Ibid., Paragraph B, p. 129.
} 


\section{THE GENERAL ARRANGEMENTS TO BORROW}

of a transaction is not disenfranchised when the Executive Board votes on the transaction. The $\mathrm{GAB}$ voting procedure effectively limits the influence of the United States and the United Kingdom, who were seen as the two most likely beneficiaries when the General Arrangements were set up.

If the necessary majorities are secured, the participants are then bound by the collective decision to lend in the general order of magnitude of the Fund's proposed call. An individual participant may still opt out, or decide to lend a smaller amount than proposed, if this is justified on balance of payments and reserve grounds; the other participants would then fill the gap. ${ }^{34}$

Taken together, these activation procedures appear complex and timeconsuming. They appear to anticipate controversy, both between the Fund and the Group of Ten, and among the members of the latter. In practice, however, such difficulties have been largely avoided. ${ }^{35}$

\section{Calls}

Under the 1962 decision, the participants to be called on, and the amounts to be called from individual participants, are based, at each activation, on two things. One is each participant's "present and prospective balance of payments and reserve position," and the second is the Fund's holdings of their currencies - that is, how much of the participants' currency subscriptions (quotas) the Fund has already used and whether it is short of a particular currency or currencies ${ }^{36}$ In practice, these criteria have been supplemented by more informal arrangements among the participants. ${ }^{37}$

After the distribution of the total call has been agreed, there is provision for an actual or prospective creditor to opt out, either at the outset or subsequently, on balance of payments and reserve grounds or to say that calls should be made for a smaller amount than proposed. The Managing Director is then authorized to arrange substitute amounts with the other

\footnotetext{
${ }^{34}$ See Gold (1979), Chap. 12, pp. 446-68; and Paragraphs C and D of Wilfrid Baumgartner's letter to GAB participants in Selected Decisions, 10th (1983), pp. 129-30.

${ }^{35}$ See Section IV.

${ }^{36}$ See Paragraph 7(b) of Executive Board Decision No. 1289-(62/1), January 5, 1962, as amended, in Selected Decisions, 10th (1983), p. 120, and Paragraph B of Wilfrid Baumgartner's letter to GAB participants, ibid., p. 129.

${ }^{37}$ See Section IV.
} 
creditors. ${ }^{38}$ This has happened on several occasions. For example, planned calls on France, in June 1968 to finance part of a U.K. drawing, and on the Deutsche Bundesbank, in February 1970 to finance part of a French drawing, were not made because of worsening in the French and German balance of payments positions, respectively.

The Fund may call the whole of an agreed total at once if the General Arrangements are being used to finance an immediate, unconditional drawing by a participant. If, however, the beneficiary's drawings on the Fund are phased under a stand-by arrangement, the Fund's calls on the $\mathrm{GAB}$ are correspondingly phased. In these cases, the Fund calls on GAB creditors, if possible in proportion to their agreed shares in the total call, each time the beneficiary draws on the Fund.

The Fund's calls on the GAB, and the Fund's related lending, thus take place simultaneously. Both sides of the transaction are effected on the same day. This procedure protects GAB creditors from sharp fluctuations in the Fund's ordinary holdings of their currencies, which determine their rights and obligations within the Fund. ${ }^{39}$

\section{Repayment}

Lending by GAB participants is, essentially, medium-term; but the repayment provisions of the 1962 decision were (and are) such that the Fund could pass through early repayments by borrowers, and participants could get their money back in a crisis. ${ }^{40}$ More specifically, the Fund is

\footnotetext{
${ }^{38}$ See Paragraph 7(d) of Executive Board Decision No. 1289-(62/1), January 5.1962, as amended, in Selected Decisions, 10th (1983), pp. 120-21.

${ }^{39}$ There is, however, some mingling of ordinary and borrowed resources so far as a GAB beneficiary is concerned. This is because, as in other Fund transactions, the beneficiary "purchases" the currencies, lent by GAB creditors, from the Fund with its own currency. This currency counterpart is mingled with the Fund's other holdings of the beneficiary"s currency, which are available for the Fund to use in its ordinary operations. The Group of Ten, however, did not want the Fund's resources effectively increased for the benefit of nonparticipants in the GAB. That was the reason for Paragraph 11(h) of the original 1962 Executive Board Decision No. 1289-(62/1), which stated that: "The Fund shall at no time reduce its holdings of a drawer's currency below an amount equal to the Fund's indebtedness to the participants resulting from transfers for the drawer's purchases." (See Horsefield and others (1969), Vol. 3, p. 250.) In other words, the Fund could not use the counterpart of the GAB loan, even though mingled, for the benefit of nonparticipants in the GAB.

${ }^{40}$ See Paragraph 11 of Executive Board Decision No. 1289-(62/1), January 5, 1962, as amended, in Selected Decisions, 10th (1983), pp. 122-24.
} 
required to repay each loan by participants after five years, or earlier if the GAB beneficiary is committed to repay the Fund within five years. The Fund is also required to make prompt repayment, in proportion to its indebtedness to participants, if the beneficiary makes an early repayment (repurchase) to the Fund.

The Fund also has the right, after consulting a participant, to make an early repayment, in full or in part, at any time. Consultation is required before early repayment to allow for the possibility that a GAB creditor may wish to retain its loan claim as a desirable reserve asset. ${ }^{41}$ The Fund has not, so far, exercised the early repayment provision, but it could perhaps be useful if, for example, the Fund's liquidity position improved dramatically soon after the General Arrangements were activated.

Of most significance to participants is the provision specifying that the Fund is bound to give "the overwhelming benefit of any doubt" 42 to a creditor requesting early repayment on the grounds of balance of payments need. This important principle, which has been incorporated into other Fund borrowing arrangements, has ensured that GAB claims are highly liquid assets which can be mobilized at very short notice. They have been mobilized on several occasions, usually when a creditor was encountering external difficulties or was itself borrowing from the Fundfor example, Canada in February 1968 (US\$35 million), Belgium in July 1969 (US\$70 million), and Italy in July 1970 (US\$330 million).

Once a repayment is made to a participant, the amount which can be called under its credit line is restored pro tanto. The credit lines are, therefore, revolving, in line with the view, shared by GAB participants and the Fund from the outset, that the General Arrangements should be something more than a temporary arrangement for a limited period. In this sense, the General Arrangements are very different from the Fund's subsequent borrowing operations.

Although the participants lend to the Fund in their own currencies, the means of repayment have always been more varied to allow flexibility on both sides. Originally, the Fund had the choice to repay either in the participant's currency "whenever feasible," ${ }^{43}$ or in gold, or, after

\footnotetext{
${ }^{41}$ See Gold (1984), Vol. 2, Chap. 6, pp. 489-90.

${ }^{42}$ See Paragraph 11(e) of Executive Board Decision No. 1289-(62/1), January 5, 1962, as amended, in Selected Decisions, 10th (1983), p. 123.

${ }^{43}$ Horsefield and others (1969), Vol. 3, p. 249.
} 
consultation with the participant, in other currencies that were "convertible in fact." ${ }^{44}$ If a participant requested early repayment on the grounds of balance of payments need, the Fund could repay in gold or in the currencies of other members that were "convertible in fact." ${ }^{45}$ The option to repay in currencies that were "convertible in fact" (which were not limited to the currencies of the ten participants) gave the Fund an extra means of repayment if a GAB beneficiary repaid the Fund in currencies other than those borrowed from the GAB. It also provided assurance to participants requesting early repayment that they could obtain currencies that would meet a balance of payments need.

In 1974-75, the option of repaying in currencies convertible in fact was replaced by "currencies that are actually convertible"-a technical, rather than a substantive, change. ${ }^{46}$ The option of repaying in SDRs was also introduced at the same time; ${ }^{47}$ and the option of repaying in gold was removed in 1978 to conform with the reduction in the role of gold under the Second Amendment of the Articles of Agreement.

\section{Transferability}

The January 1962 Decision provided that a participant could not transfer all or part of its GAB claims, except with "the prior consent" of

\footnotetext{
${ }^{44}$ Ibid.

${ }^{45}$ See Paragraphs 11(a) and 11 (f) of Executive Board Decision No. 1289-(62/1), January 5, 1962, in Horsefield and others (1969), Vol. 3, pp. 249 and 250, respectively. The concept of a currency "convertible in fact" was introduced into the GAB decision for several reasons. Perhaps the most important was that the Japanese yen had not yet become convertible in the Fund's sense, under Article VIII, although it was broadly convertible in the market. It was implicitly understood that the currencies of all ten GAB participants should, in principle, qualify as currencies in which repayment could be made. The currencies of nonparticipants could also qualify. It was also recognized that a currency which was convertible under Article VIII might be subject to restrictions on current payments and transfers and would not, therefore, be a suitable means of repayment. A detailed account of the rationale behind this concept is contained in Gold (1971).

${ }^{46}$ See Executive Board Decision No. 4421-(74/132), October 23, 1974, in Selected Decisions of the International Monetary Fund and Selected Documents, Eighth Issue (May 10, 1976), p. 113. Under the First Amendment of the Articles of Agreement in 1969, the concept of a currency "convertible in fact" had been given a technical meaning in the provisions relating to the SDR facility. To avoid confusion, it was therefore replaced in the GAB decision by "currencies that are actually convertible." The new language was chosen, as the original had been, primarily to ensure that the Fund could repay in the currency of any of the GAB participants.

${ }^{47}$ The SDR facility was established, after the GAB, as part of the First Amendment of the Articles of Agreement in 1969.
} 
the Fund and "on such terms and conditions as the Fund may approve." 48 The restrictive language was based on the Fund's understandable concern that GAB claims should not be transferred either to another participant in a vulnerable external position or to a nonparticipant who might encash the claim, thus causing refinancing difficulties for the Fund. The Fund was also reluctant to allow the transfer of interest-earning claims to members who were using its resources.

In practice, these provisions have not stood in the way of transfers between GAB participants, which have enhanced the liquidity of GAB claims. In June 1968, for example, when France borrowed from the Fund, its outstanding claims under the GAB, equivalent to US\$140 million, were transferred to Belgium, the Deutsche Bundesbank, Italy, and the Netherlands. Again, in December 1969, the Fund consented to the transfer by the Deutsche Bundesbank of claims totaling US $\$ 210$ million to Canada, Italy, Japan, and the Netherlands. ${ }^{49}$

The provisions were also updated and broadened, at the participants' request, in March 1979, when the Executive Board decided to give participants freedom to transfer, at any time, all or part of their GAB claims to another participant, at a mutually agreed price, provided that the transferee had a remunerated (income-earning) reserve-tranche position in the Fund and had no outstanding repurchase obligations to the Fund. ${ }^{50}$ Transfers involving the Swiss National Bank were also allowed, with provisions made to protect the Fund's liquidity. ${ }^{51}$ The March 1979 Decision effectively legalized the status quo and brought the GAB more into line with the comparable provisions in the supplementary financing facility. ${ }^{52}$

\section{Interest Rate}

Claims on the Fund under the GAB were secure, as well as liquid, investments. They were as good as gold because their value was

\footnotetext{
${ }^{48}$ See Paragraph 13 of Executive Board Decision No. 1289-(62/1), January 5, 1962, as amended, in Selected Decisions, 10th (1983), p. 124.

${ }^{49}$ de Vries (1976), Vol. 1, Chap. 19, pp. 370-97.

${ }^{50}$ Executive Board Decision No. 6068-(79/47), March 21, 1979, in Selected Decisions, 10th (1983), pp. 146-47.

${ }^{51}$ See subsection 10, "Association of Switzerland,"

${ }^{52}$ The March 1979 Decision was amended and updated in 1984. See Section V.
} 
maintained in terms of gold. They were, in fact, better than gold because the Fund originally paid interest, in gold, at a rate of 1.5 percent per annum, together with a $1 / 2$ of 1 percent transfer charge on each loan. ${ }^{53}$

The interest rate was not high, partly because the General Arrangements were seen as a cooperative effort to protect the system and partly because GAB claims had other-desirable — qualities, which have already been referred to. Also, at the time, the Fund was not obliged to pay remuneration on credit extended by members to finance the Fund's ordinary transactions with other members. There was, however, provision in the original Articles of Agreement for a discretionary, preferential distribution of net income of up to 2 percent on average net creditor positions, and this was one reference point in determining the 1.5 percent rate on GAB loans. The inclusion of a transfer charge provided creditors with additional income. The more technical justification was to compensate creditors for possible exchange losses arising from a creditor lending its own currency but being repaid in other currencies it might not want to retain. ${ }^{54}$

A new interest rate formula was, however, adopted in 1975, at the time of the third renewal of the GAB, when it was agreed that the Fund should pay interest quarterly to $\mathrm{GAB}$ creditors at the same rate it levied charges on drawings financed by GAB borrowing but, in any event, not less than 4 percent per annum. ${ }^{55}$ This was a compromise between prospective GAB creditors, who wanted a higher market-related interest rate-for example, the 5 percent agreed in June 1974 for the SDR interest rate - and the Fund, which wanted to protect its income position and avoid financial loss in $\mathrm{GAB}$ transactions. As it was, the new formula, together with the transfer charge, which was retained despite some support for its abolition among GAB participants, meant that the Fund received no net income on transactions financed with GAB resources in the late 1970s. On the other

\footnotetext{
${ }^{53}$ See Paragraph 9 of Executive Board Decision No. 1289-(62/1), January 5, 1962, in Appendix I of this pamphlet. The paragraph also provided that if the 1.5 percent rate became different from a "basic rate" determined with reference to the charges then levied by the Fund on members' drawings, the Fund would pay interest at the basic rate.

${ }^{54}$ See Gold (1984), Vol. 2, Chap. 6, p. 491; and subsection 6, "Repayment."

${ }^{55}$ See Paragraph 9 of Executive Board Decision No. 1289-(62/1), January 5, 1962, as amended, in Selected Decisions, 10th (1983), p. 121.
} 
hand, GAB creditors were not overcompensated, since Fund charges were well below market interest rates. ${ }^{56}$

In 1975, it was also agreed, that payments of interest and charges by the Fund - as well as repayments of loans (discussed earlier) — could be made in SDRs, the participant's currency, or other actually convertible currencies. The option of paying in gold was retained, since the controversy about the role of gold in the system was still unresolved; it was, however, removed in $1978 .{ }^{57}$

\section{Renewal and Modifications}

The General Arrangements became effective in October 1962, when the participation requirements, namely adherence by at least seven participants with credit lines of at least US\$5.5 billion, were met. Canada was the last participant to join, in January 1964. Initially established for four years, the GAB was renewed for four more years from 1966, and for further periods of five years from 1970, 1975, and 1980.

Renewals, and modifications at the time of each renewal, are decided by the Fund, by a simple majority of the votes cast in the Executive Board, not later than 12 months before the end of the current period of effectiveness. The concurrence of the participants is not required in these decisions, but participants have a unilateral right to withdraw from the $\mathrm{GAB}$, as renewed, within a specified time. None have done so. In practice, the participants can exert decisive influence on renewals and modifications through their combined voting power on the Executive Board. Amendments to the GAB at any other time require the concurrence of all participants, as well as a decision by the Executive Board. ${ }^{58}$

These provisions have helped to keep changes to a minimum. Those changes that occurred before 1982-83, which were described earlier, have

\footnotetext{
${ }^{56}$ This was particularly so in 1978 when the Fund called on the GAB to help finance an interest-free reserve-tranche drawing by the United States. In line with the new formula, the Fund paid the two GAB creditors, the Deutsche Bundesbank and Japan, the minimum 4 percent rate for the five years their loans were outstanding. But this rate was below the rate of remuneration which the Fund paid creditor members for use of their ordinary (quota) resources following the Second Amendment of the Articles of Agreement. In this case, the General Arrangements were a relatively cheap source of money for the Fund.

${ }^{57}$ See Paragraph 9(c) of Executive Board Decision No. 1289-(62/1), January 5, 1962, as amended, in Selected Decisions, 10th (1983), p. 121: and subsection 6, "Repayment."

${ }^{58}$ See Paragraphs 15, 16, and 19 of Executive Board Decision No. 1289-(62/1), January 5, 1962, as amended, in Selected Decisions, 10th (1983), pp. 125-27.
} 
been responses to outside developments, such as related changes in Fund procedures and practices. They have been incidental rather than fundamental. The potentially important provisions for new participants were not used. Those for increasing the amount of individual credit lines ${ }^{59}$ were used only once (which will be explained later).

\section{Association of Switzerland}

The General Arrangements were, however, strengthened by the association of Switzerland, which is not a member of the Fund, in June 1964. ${ }^{60}$ Discussions between the Fund and Switzerland took place from early 1962 onward. From the Fund's standpoint, it was sensible to close the gap in the GAB framework, since Switzerland was one of the main countries from which and to which short-term capital flowed. Linking Switzerland to the GAB was also seen as a possible way of encouraging Switzerland to join the Fund. The Swiss interest in an association agreement was to attain a formal standing within the Group of Ten and to expand their domestic legislative authority to make international loans. Indeed, once the association agreement was established, the Swiss preferred to lend to the Fund outside the rather cumbersome provisions of that agreement.

Under the association agreement, which has been extended at each renewal of the GAB, Switzerland was prepared, but not obliged, to make resources available to $\mathrm{GAB}$ participants up to a maximum of Sw F 865,000,000 (US\$200 million in 1964) when a participant was drawing from the Fund and the General Arrangements were being activated. The terms and conditions were similar, but not identical, to those for other GAB creditors, except that a loan by Switzerland did not go through the Fund but was made directly to the GAB beneficiary. It also required a separate implementing agreement between Switzerland and the GAB beneficiary. Switzerland was free to decide both whether to enter an implementing agreement and whether to lend under it. In part, this was because of the GAB precedent and also because Switzerland, at that time,

\footnotetext{
${ }^{59}$ See Paragraphs 3 and 5, ibid., pp. 118-19.

${ }^{60}$ See "Exchange of letters between the Ambassador of Switzerland to the United States and the Managing Director of the Fund," dated June 11, 1964, in Selected Decisions, 10th (1983), pp. 148-52.
} 
thought there would be more justification to lend to the two reservecurrency countries than to other participants. ${ }^{61}$

The association agreement was formally activated in November 1964 and May 1965, when the General Arrangements were first used to finance two large drawings on the Fund by the United Kingdom. On these occasions, implementing agreements were concluded between the Swiss National Bank and the Bank of England for the equivalent of US\$80 million and US\$40 million, respectively. A different procedure was, however, followed in December 1976 and April 1977, when the Swiss National Bank participated in financing stand-by arrangements for the United Kingdom and Italy. In these later cases, the Fund and Switzerland found it quicker and simpler to set up ad hoc loan agreements "at call" with the Swiss National Bank for the equivalent of SDR 300 million and SDR 37.5 million, respectively. ${ }^{62}$

The association of Switzerland increased the resources available to the Fund in two ways-directly through the extra US\$200 million, and indirectly since Switzerland was not a member of the Fund and could not borrow from it under the GAB. ${ }^{63}$ It meant there was more available for the other participants, and it helped the Fund to spread the financing burden when the General Arrangements were activated.

\section{Increase in Japan's Credit Line}

The only change, before 1983, in the amounts of the original credit lines was in November 1976, when Japan increased its credit line from $¥ 90,000,000,000$ (then equivalent to about SDR 265 million) to $¥ 340,000,000,000$ (about SDR 1,000 million). The increase reflected the rapid growth of Japan's economy and its growing importance in the

\footnotetext{
${ }^{61}$ See Gold (1979), Chap. 12, pp. 446-68.

${ }^{62}$ See "Borrowing Agreement with Swiss National Bank, 1976" and "Borrowing Agreement with Swiss National Bank, 1977," in Selected Decisions, 10th (1983), pp. 15256 and pp. 156-60, respectively. It should also be noted that some of the provisions in these two agreements, and in other Fund borrowing agreements, were very much influenced by the provisions of the $\mathrm{GAB}$.

${ }^{63}$ There was, however, a provision, which was never exercised, in the June 1964 association agreement for Switzerland and a GAB participant with which Switzerland had an implementing agreement, to "make resources available to each other... on the basis of reciprocal terms if required." (See letter from the Ambassador of Switzerland to the United States to the Managing Director of the Fund, June 11, 1964, in Selected Decisions, 10th (1983), p. 149.)
} 
international financial and trading system since the early 1960s. It also reflected the more immediate concern of Fund management that the organization should have sufficient resources to meet prospective demands from the United Kingdom and Italy, who were, at that time, engaged in preliminary negotiations for stand-by arrangements. Japan, for its part, was willing to strengthen the Fund so that it could encourage these, and other, deficit countries to adjust without recourse to import controls and payments restrictions. Japan also wanted to strengthen its case for an increased quota share in the Fund at the next general review of quotas.

In retrospect, the immediate factors were probably more significant, since the relative economic and financial positions of the other participants had also changed considerably. This, in turn, underlines the essentially passive nature of the GAB since 1962 and the need for some kind of crisis - in 1976, an imminent shortage of Fund liquidity-to provoke fundamental changes. Even then, allowing for exchange rate changes after 1962 (discussed later on), the increase in Japan's credit line simply raised the overall size of the GAB to the equivalent of approximately SDR 6,200 million, or only slightly more than the original total.

\section{The GAB in Operation, 1962-82}

On the one hand, the General Arrangements have strengthened the Fund considerably. They have enabled the Fund to assist its largest members on an adequate scale. They have also allowed the Fund to preserve its ordinary resources, at least to some extent, ${ }^{64}$ for drawings by other members who do not belong to the Group of Ten. The Fund's access to such a reserve pool of currencies has strengthened its authority and provided an element of confidence at times of crisis in the exchange markets. On the other hand, the General Arrangements have always been unpopular with nonparticipants. In addition, the participants' inability to adapt the GAB to the far-reaching changes in the international monetary system after 1971 gave rise to growing doubts about its role and adequacy.

${ }^{64}$ See subsection 2, "Principles and Practices." 


\section{Activations}

\section{a. The $1960 \mathrm{~s}$}

Between 1964 and 1970, the General Arrangements were activated six times to help the Fund finance four large drawings by the United Kingdom and two by France. Total Fund borrowing from the GAB in this period amounted to the equivalent of US\$2,155 million, all of which had been repaid by August 1971. The details are shown in Table 2 .

The United Kingdom's recourse to the Fund and the Fund's recourse to the GAB to help meet the U.K. requests were not unexpected. The General Arrangements had, after all, been designed primarily to finance large conditional drawings on the Fund (in the so-called credit tranches) by the two reserve centers. The United Kingdom's current account was weak for much of the 1960 s, but the policy options, especially devaluation, were limited by the reserve-currency role of the pound sterling and the sizable overhang of sterling balances held in London, principally by Commonwealth countries. Pressure on sterling intensified from 1964 onward, and the U.K. authorities were forced into a series of measures, first to resist and then, in 1967, to support a devaluation. As well as borrowing from the Fund, these measures included BIS credits, central bank swaps, and payments restrictions.

The General Arrangements were also activated for France, in similar circumstances to those of the United Kingdom, first to resist a devaluation of the franc in 1968, and then to support one in 1969. The French balance of payments position was not strong at this time; and the devaluation of the pound sterling in November 1967 was followed by intense speculation in other currencies, in anticipation of more frequent parity changes, and by flights into gold, which led to the creation of a two-tier gold market in March 1968. Speculation regarding the exchange rates for the French franc and the deutsche mark continued through mid-1969, until the French franc was devalued in August and the deutsche mark was revalued in October.

In view of the GAB's central purpose, it was perhaps surprising that they were not activated for the United States in the 1960s. On the other hand, successive U.S. administrations were unwilling, for domestic political reasons, to accept the conditions attached by the Fund to drawings in the credit tranches. The U.S. drawings in this period were 
TABle 2. Fund Financing Involving the GAB, $1964-70$

(In millions of U.S. dollars)

\begin{tabular}{|c|c|c|c|c|c|c|c|c|}
\hline \multirow[b]{2}{*}{ Date } & \multirow[b]{2}{*}{$\begin{array}{c}\text { Purchasing } \\
\text { Member }\end{array}$} & \multirow[b]{2}{*}{$\begin{array}{c}\text { Amount } \\
\text { Pur- } \\
\text { chased }\end{array}$} & \multicolumn{6}{|c|}{ Financed by: } \\
\hline & & & GAB & $\begin{array}{c}\text { Per- } \\
\text { centage } \\
\text { of total }\end{array}$ & $\begin{array}{l}\text { Fund } \\
\text { gold } \\
\text { sales }\end{array}$ & $\begin{array}{c}\text { Per- } \\
\text { centage } \\
\text { of total }\end{array}$ & $\begin{array}{l}\text { Fund } \\
\text { currency } \\
\text { holdings }\end{array}$ & $\begin{array}{c}\text { Per- } \\
\text { centage } \\
\text { of total }\end{array}$ \\
\hline Dec. 1964 & United Kingdom & 1,000 & 405 & (41) & 250 & (25) & 345 & (34) \\
\hline May 1965 & United Kingdom & 1,400 & 525 & (38) & 400 & (28) & 475 & (34) \\
\hline Nov. 1967 & United Kingdom & 1,400 & 476 & (34) & 365 & (26) & 559 & $(40)$ \\
\hline June 1968 & France & 745 & 265 & (36) & 182 & (24) & 298 & (40) \\
\hline June 1969 & United Kingdom & 500 & 200 & $(40)$ & 50 & (10) & 250 & $(50)$ \\
\hline \multicolumn{9}{|l|}{ Sept. 1969/ } \\
\hline \multirow[t]{2}{*}{ Feb. 1970} & France & 985 & $284^{1}$ & (29) & 200 & (20) & 501 & $(51)$ \\
\hline & Total & 6,030 & 2,155 & (36) & 1,447 & (24) & 2,428 & $(40)$ \\
\hline
\end{tabular}

${ }^{1}$ This was the amount actually drawn from the GAB. It was less than the amount activated ( $\$ 375$ million), because the amount proposed for the Deutsche Bundesbank was reduced by $\$ 90$ million following a change in the Federal Republic of Germany's balance of payments. 
made partly for technical reasons; they were all within the unconditional gold tranche; and they were financed without recourse to the GAB. ${ }^{65}$

The Fund was also able to finance drawings by other participants, notably in 1968-69, when the foreign exchange markets were extremely volatile, without using the GAB. The drawings were all within the gold tranche and were therefore relatively limited; and the Fund's ordinary currency holdings were strengthened in early 1966 by a further general quota increase of 25 percent, together with special increases for certain "strong" countries.

\section{b. The 1970s}

The General Arrangements were activated three times in the 1970s. They were used to help finance large drawings, by the United Kingdom in January 1977, by Italy in May 1977, and by the United States in November 1978. The details of how the Fund financed these drawings are shown in Table 3.

The United Kingdom and Italy came to the Fund more than once in this period. From 1974 to 1976, Italy drew SDR 1,455 million under the oil facility and SDR 1,000 million under a stand-by arrangement. In late 1975, the United Kingdom drew SDR 1,000 million under the oil facility and SDR 700 million under a stand-by arrangement in the first credit tranche. The oil facility drawings were financed by bilateral borrowing from oil producers and industrial countries with balance of payments surpluses; the stand-by arrangements were financed out of the Fund's ordinary currency holdings, which were adequate for the purpose.

But such assistance, much of it provided on easy terms, was not accompanied by sufficient adjustment to the effects of higher oil prices or

\footnotetext{
${ }^{65}$ In 1964, 1965, and 1966, for example, the Fund's holdings of dollars were in excess of 75 percent of quota, and the Fund consequently could not accept dollars from other members in repayment. The United States therefore made drawings in currencies which the Fund could accept in repayment and made these currencies available to countries holding dollars who wished to repay the Fund. In 1966, the United States also drew US\$250 million in Italian lire so that it could buy back from Italy an equivalent amount of dollar holdings. Because the Fund's holdings of lire were low, it borrowed lire, bilaterally, from Italy, outside the GAB - the only occasion, before 1974, of bilateral borrowing by the Fund. The United States drew again in 1968 and 1970, when it needed specific currencies to redeem official dollar holdings held abroad; and it made its largest drawings, still within the gold tranche, in the first half of 1971 (US\$1,362 million), just before the suspension of dollar/ gold convertibility.
} 
TABle 3. Fund Financing Involving the GAB, 1977-78

(In millions of SDRs)

\begin{tabular}{|c|c|c|c|c|c|c|c|c|}
\hline \multirow[b]{2}{*}{ Date } & \multirow[b]{2}{*}{$\begin{array}{c}\text { Purchasing } \\
\text { Member }\end{array}$} & \multirow[b]{2}{*}{$\begin{array}{c}\text { Amount } \\
\text { of } \\
\text { Purchase }\end{array}$} & \multicolumn{6}{|c|}{ Financed by: } \\
\hline & & & GAB & $\begin{array}{c}\text { Per- } \\
\text { centage } \\
\text { of total }\end{array}$ & $\begin{array}{c}\text { Swiss } \\
\text { National } \\
\text { Bank }\end{array}$ & $\begin{array}{c}\text { Per- } \\
\text { centage } \\
\text { of total }\end{array}$ & $\begin{array}{c}\text { Fund } \\
\text { currency } \\
\text { holdings }\end{array}$ & $\begin{array}{c}\text { Per- } \\
\text { centage } \\
\text { of total }\end{array}$ \\
\hline Jan. 1977 & United Kingdom & $3,360^{1}$ & 2,560 & (76) & 300.0 & (9) & 500 & (15) \\
\hline May 1977 & Italy & $450^{1}$ & 337 & (75) & 37.5 & (8) & 75 & (17) \\
\hline Nov. 1978 & United States & 2,275 & 777 & (34) & - & & 1,498 & (66) \\
\hline
\end{tabular}

${ }^{1}$ Proposed but not fully drawn. 
by sustained efforts to deal with structural weaknesses. It did not, therefore, restore external confidence in the two countries' policies or in their currencies, which remained extremely vulnerable through successive exchange market crises in 1976. First the United Kingdom, and then Italy, was forced by exchange market pressures and acute balance of payments problems to go back to the Fund for large amounts, on stringent conditions, when the latter's liquidity was already under strain. ${ }^{66}$

The General Arrangements were also activated to deal with another crisis in the exchange markets. This time it was the dollar, which had depreciated sharply against the other major currencies from September 1977 through October 1978 despite a series of (unsuccessful) measures by the Carter Administration to turn the tide. In November 1978, the U.S. authorities mobilized the equivalent of US $\$ 30$ billion, mainly in deutsche mark and yen, to defend the dollar; the package included large sales of SDR holdings and a sizable reserve-tranche drawing on the Fund. ${ }^{67}$

\section{Principles and Practices}

Despite their highly contingent character, the General Arrangements have been a valuable source of supplementary finance for the Fund, as the architects envisaged. In practice, as the various activations show, they have been available to cover conditional and unconditional drawings whenever a participant (not just a reserve center) was in serious difficulties, whatever the cause, and the Fund was, or was likely to be, short of resources. ${ }^{68}$ In each case, the objective of preserving the stability of the system has been interpreted very broadly by the Fund and the GAB participants.

Just as important, the activation procedures have operated with considerable flexibility. Informal advance consultations between the Managing Director and the participants have kept possible differences to a

\footnotetext{
${ }^{66}$ For a comprehensive account of the drawings by Italy and the United Kingdom, see de Vries (forthcoming),Vol. 1, Chaps. 23 and 24, respectively.

${ }^{67}$ For a comprehensive account of the U.S. drawing, see de Vries (forthcoming). Vol. 2, Chap. 44.

${ }^{68}$ See Section III. As explained earlier, the participants confirmed in mid-1968 that the GAB could be used to cover drawings, including gold-tranche drawings, by all participants. The Fund asked for such confirmation at that time because the exchange markets were unsettled and its ordinary holdings of participants' usable currencies were low. This is described in de Vries (1976), Vol. 1, Chap. 19, pp. 370-72.
} 
minimum. The elaborate safeguards in the Baumgartner letter have not had to be called on. The Deputies of the Group of Ten, normally meeting in Paris, have considered the policies and the balance of payments prospects of prospective GAB beneficiaries on the basis of reviews prepared in the OECD's Working Party $3 .^{69}$ Fortunately, these assessments by the Group of Ten have been similar to those of the Fund. The Group of Ten has only rarely sought to change the terms on which the Fund proposed to on-lend GAB resources. The Group of Ten has never objected to a proposal by the Managing Director, nor has it had to vote on such a proposal.

The activation procedures have also operated swiftly, owing largely to the close, informal links between Fund management and the Group of Ten's Executive Directors in Washington, and to the regular contacts among the Group of Ten's Finance Ministers and among their Deputies. The procedures were, in fact, accelerated in November 1978, when the General Arrangements were used to finance part of the emergency reserve-tranche drawing by the United States.

Similarly, the distribution of calls among the GAB participants has been settled informally, at each activation, on the basis of an initiative by the Managing Director. Haggling among the participants has been the exception rather than the rule. In practice, the participants were quick to develop a concept of solidarity to show their public support for the GAB beneficiary. As a result, almost all the participants were often included in a package, sometimes for nominal amounts, irrespective of the economic criteria. To date, the U.K. credit line is the only one not to have been called on by the Fund. (The distribution of the Fund's calls are shown in Appendix V, Tables 5 and 6.)

Informality, but of a different kind, also prevailed in 1978, when the Fund's calls on the GAB to finance the U.S. drawing were confined to two participants, the Deutsche Bundesbank and Japan. The United States particularly wanted to borrow deutsche mark and yen to help support the dollar. Although there was considerable discussion about the legality of doing so, the participants were willing to go along with the U.S. preference.

${ }^{69}$ This group of senior officials of the Group of Ten came to play an increasingly important role in influencing Fund policies and conditionality, in particular, from the mid1960 s onward. 
Other informal practices developed in response to the wishes of the participants. For example, (as Table 2 shows) the participants wanted the Fund to combine calls on the General Arrangements with use of its ordinary currency holdings, in order to avoid the impression of a "special fund" which enabled them to do without the Fund's ordinary resources. ${ }^{70}$ Perhaps more significant was the practice of combining the Fund's calls on the GAB, in the 1960s, with sizable sales of Fund gold to the participants, in exchange for needed currencies. These sales, for which there were respectable precedents, ${ }^{71}$ were made at the strong insistence of the Group of Ten for political, as well as economic, reasons. The Group of Ten felt that the Fund's gold holdings should be mobilized to spread the financing burden. The members of the Group of Ten also wanted to acquire gold, which could be sold in an emergency, particularly as they were being asked to lend or commit an increasing proportion of their foreign exchange reserves to the Fund. The precise amount of gold to be sold was determined by the Fund, in consultation with the GAB participants, on each occasion.

These gold sales were not, however, popular with some of the Fund's other members, nor with some of the Fund staff. Those who disliked the sales felt that the Fund's gold stock should be preserved, as much as possible, to underpin the Fund's financial position or for use, if at all, in a crisis affecting all Fund members and not simply for the benefit of a single member of the Group of Ten. The wish to economize on the use of the Fund's gold was one important reason why the General Arrangements were not used more in the late 1960s.

In the late 1970s, however, the Fund was no longer in a position to replenish its stock of currencies through gold sales, an impasse arising from the tortuous compromises on the disposal of the Fund's gold. The Fund, therefore, had to rely much more heavily on the GAB to finance the U.K. and Italian drawings than in similar circumstances in the 1960s (see Table 3). This reliance was heightened by the Fund's shortage of usable currencies stemming from more frequent drawings by the non-oil developing countries and delays in ratifying the quota increases that had been decided on during the Sixth General Review of Quotas. In the event,

\footnotetext{
${ }^{70}$ See Gold (1984), Vol. 2, Chap. 6, p. 491.

${ }^{71}$ The Fund had sold gold to the United States in the 1950s, to replenish its stock of dollars, and to the major industrial countries in 1961, to help finance a large U.K. drawing.
} 
the stand-by arrangements with the United Kingdom and Italy were remarkably successful in promoting a rapid restoration of confidence in both countries; and the amounts actually called from GAB participants and the Swiss National Bank were considerably less than the amounts proposed. ${ }^{72}$

\section{Critics}

Although the General Arrangements were useful for the Fund, and although they operated flexibly, the controversy over gold sales (described earlier) was only one example of the GAB's unpopularity. They have always been controversial.

From the outset, the Executive Board was "not enthralled" by the arrangements, and some members were "overtly critical" of the nonglobal aspects. ${ }^{73}$ Several countries, and not solely developing countries, resented the GAB because they were exclusive. The number of participants was limited, and they had agreed to lend to the Fund only to finance their own transactions with it. Second, the General Arrangements were seen as reducing the Fund's authority. They were only an agreement to agree. They gave a small club of rich members an effective veto over important decisions by the Fund to enter into transactions. Third, the General Arrangements, and the Baumgartner letter in particular, were the raison d'etre of the Group of Ten, which began, very quickly, to play a much greater role in discussing Fund issues. Indeed, many of the studies of international liquidity, and the main negotiations which led to the creation of the SDR in 1969, were conducted within the Group of Ten. This later prompted the developing countries to form their own group, the Group of 24 , in November 1971, initially to ensure that their voice would be heard in the negotiations, which were then getting under way, on international monetary reform and also to protect the interests of the developing countries in the monetary field more generally. ${ }^{74}$

\footnotetext{
${ }^{72}$ See Table 6 in Appendix V.

${ }^{73}$ See Jacobsson (1979), pp. 383 and 384, respectively; and Horsefield (1969), Vol. 1, Chap. 19 , pp. 495-522.

${ }^{74}$ See Gold (1984), Vol. 2, Chap. 6, pp. 496-98 and 508-509. Gold notes that the (apparently divisive) formation of two groups of Fund members produced the reaction that issues affecting the system as a whole should be considered in bodies which represented the community as a whole. This is evident in the broad composition of the Fund's Committee of Twenty and its successor, the Interim Committee. Many developing countries, however, would still argue that it is the Group of Ten, or rather its major members led by the United States, which takes or blocks the key decisions and moves the Fund in the direction the Group of Ten wants, irrespective of the forum for discussion.
} 


\section{THE GENERAL ARRANGEMENTS TO BORROW}

These (understandable) concerns were not dispelled by arguments that the participants had acquired new responsibilities and not just new rights, or that the existence of the GAB left more of the Fund's ordinary resources available for transactions with other members. These concerns were another important reason why the General Arrangements have not been used more frequently. There has been a widely shared feeling, among nonparticipants and among the Fund staff, that the Fund should not go "cap in hand" to the Group of Ten if this could be avoided.

These concerns have persisted to the present day. The developing countries, in particular, have acquiesced only reluctantly in successive renewals of the GAB. They have periodically called for the Fund to rely more on its ordinary quota-based resources or for replacing the General Arrangements with broader borrowing arrangements available to all Fund members.

\section{Reforms Postponed}

The participants themselves re-examined the GAB on several occasions before 1982, but very little came of it.

In 1965, for example, prior to the first renewal, the possibility of relaxing or abolishing the requirement that the international monetary system be in danger of impairment and the possibility of simplifying the activation procedures were raised. But the discussions were inconclusive. In mid-1968, before the second renewal, the Fund staff and management saw merit in far-reaching changes, such as increasing the individual credit lines or admitting new participants. But they suspected that the participants would not be receptive. They were right. Again, in 1969 and 1970, the Fund toyed with updating the GAB following the First Amendment of the Articles of Agreement. But, although some of the proposed changes were seen as perhaps desirable, the Executive Board saw no urgency.

The participants' reluctance to change things in the 1960s was, in many ways, understandable. The General Arrangements were still relatively new, and they had served their purpose adequately. They remained a valuable defense against temporary strains in the Bretton Woods system.

In the 1970s, however, the General Arrangements were operating in conditions very different from those for which they had been designed. Their role, and that of the Fund itself, was much less clear cut. The par 
value system was replaced by a nonsystem ${ }^{75}$ of more or less managed floating exchange rates among the major industrial countries; and the world economy experienced profound changes in the wake of the major oil price increases in 1973-74. The authority of the Fund was weakened, particularly in the area of exchange rates, and its resources were limited relative to the scale of the oil-related imbalances. The Fund's ability to influence, much less control, the process of international liquidity creation was overtaken by the unparalleled expansion of the Euromarkets, which assumed the task of recycling the oil surpluses to deficit countries.

At the same time, the oil price increases in 1973-74 and 1979-80 shifted the balance of economic and financial power away from the GAB participants. In the 1970s, the Fund borrowed extensively, but the Group of Ten was no longer the sole, or even the main, provider of supplementary resources. The Fund relied more on the oil producers, and Saudi Arabia in particular, to finance first the 1974-75 oil facilities; then the supplementary financing facility; and, more recently, the enlarged access policy.

Against this background, the General Arrangements declined in relative size and importance. Even after the increase in Japan's credit line in 1976, the GAB's overall size remained very close to what it had been in 1962, because of the effects of exchange rate changes on the value of the individual commitments (measured in SDRs). Although the credit lines of the Deutsche Bundesbank and Japan increased as the deutsche mark and the yen appreciated against the SDR, those of the United Kingdom, the United States, and Italy fell sharply. By mid-1982, the General Arrangements totaled some SDR 6.3 billion, which was equivalent to only 20 percent of participants' Fund quotas, compared with 60 percent in 1962 , and to only 2 percent ( 15 percent) of their reserves. Thus, although the General Arrangements were used in 1977-78, it became increasingly doubtful whether their resources were sufficient for the original purpose of impressing the exchange markets and preventing crises.

Not surprisingly, therefore, there was more talk of reform. But little was accomplished. In 1975, at the time of the third renewal, only two noteworthy changes were made - namely, the higher interest rate formula and the extension of the media in which the Fund could pay interest and

${ }^{75}$ Williamson (1977). 
repay creditors. ${ }^{76}$ As in the past, the Fund staff considered radical reforms. These included increasing both the amounts and the number of currencies which participants would lend, ending the restriction on use of the GAB to finance drawings by only the Group of Ten, and widening the range of circumstances in which the Fund could call on the GAB. The more far-reaching possibility was also raised informally with the participants of replacing the GAB with bilateral credit arrangements, between the Fund and the major industrial countries, on the lines of the 1974 oil facility. This would have given the Fund more flexibility than it had under the GAB.

But these proposals came to nothing, in part because the Fund's management did not wish to provoke controversy and protracted negotiations which might have jeopardized renewal of the GAB. Some of the proposals would have required new legislative authority which might not have been easy for certain participants, particularly the United States, to obtain. Several members of the Group of Ten preferred to keep the basic elements of the GAB unchanged as an agreed basis for joint action in a crisis, rather than starting again with a new, and untried, set of arrangements.

In 1977-78, the General Arrangements were updated to conform with the Second Amendment of the Articles of Agreement. The updating was, however, confined to a limited number of essentially formal changes which followed more or less automatically from the new Articles and consequent changes in Fund practices. More importantly, the role of the GAB was reviewed by the Deputies of the Group of Ten in AprilSeptember 1978. The review was ostensibly far-reaching, but the results were not.

More specifically, the participants concluded that the General Arrangements had, on the whole, worked quite well, and that they should be maintained as a potentially valuable means of additional financing for the Fund. They were, however, unable to agree on even a modest increase in the total size of the GAB. Some were prepared to accept this, on certain conditions; but the most powerful participants, the United States and the Federal Republic of Germany, favored the status quo. The inability of participants to agree on this question ruled out any attempt to rearrange the shares of individual participants.

\footnotetext{
${ }^{76}$ See Section III.
} 
Other, more radical proposals received even less support. There was no enthusiasm for including new participants, such as other OECD countries or the oil producers in structural balance of payments surplus. This lack of enthusiasm was not new. Although individual participants were prepared, at different times, to consider new participants-Austria, Spain, and others - there were always one or more opponents. The Group of Ten thought that the cohesion of the participants was a major reason for the effective functioning of the General Arrangements, the implication being that they could become less effective if the circle of participants was ever widened. At most, the Group of Ten thought that it might be useful to exchange views, periodically, with lenders to the Fund under other borrowing agreements, but no action was necessary at that time.

Similarly, the participants felt that access to the GAB should continue to be limited to the Group of Ten countries. In part, this was because the $\mathrm{GAB}$ appeared, by then, to be inadequate to finance concurrent drawings on the Fund by the Group of Ten, let alone other countries. The participants also felt that the Fund could run into liquidity problems, in meeting Group of Ten drawings, if the General Arrangements became a frequently and regularly used part of Fund resources.

It was also impossible for the participants to reach a consensus on a new interest rate formula for GAB loans. Some wanted a higher, marketrelated rate, but others thought the Fund should receive net income from GAB-financed loans. Some were prepared to forgo all or part of the transfer charge to benefit the Fund's financial position, but most wanted to keep it. The compromise provisions adopted in $1975^{77}$ were therefore retained.

It was also decided not to change the denomination of the individual credit lines from national currencies to SDRs. Although it was recognized that exchange rate changes, particularly since the breakdown of the par value system, had had an uneven impact on the distribution of the financing burden, some participants felt that changes in the SDR value of these credit lines reflected changes in the underlying capacity of participants to provide financing. ${ }^{78}$ Some participants also saw practical and legal problems in changing to SDR denomination. So nothing was done.

\footnotetext{
${ }^{77}$ See Section III.

${ }^{78}$ This view was consistent with the original rationale for denominating the credit lines in the national currencies of the participants. See Section III.
} 


\section{THE GENERAL ARRANGEMENTS TO BORROW}

The only changes which were made were relatively minor. The first was to enhance the liquidity of $\mathrm{GAB}$ claims by making them more easily transferable among participants. ${ }^{79}$ The second was an understanding to permit, on an ad hoc basis, GAB loans to remain outstanding longer than five years if the related Fund credit to a participant was granted for longer than five years. This was to cover the possibility of the Fund granting an extended arrangement, with longer repayment provisions, to a participant. But this has not happened so far.

The General Arrangements therefore stayed virtually the same from 1962 to 1982 . There were, perhaps, three main reasons for this inertia, particularly in the 1970s. First, the participants viewed the Fund as a less necessary line of support in this period. The shift from fixed to floating exchange rates provided the participants with a wider range of policy options. There was less need for them to defend a particular exchange rate, less need to approach the Fund to support such action, and less need for the Fund to use the General Arrangements.

Second, the rapid growth of the Euromarkets as a source of credit to country borrowers offered a more expensive but unconditional alternative to Fund borrowing. The expansion of the Federal Reserve's swap network and the creation of new short- and medium-term financing facilities by the European Community also provided other sources of official credit for the main industrial countries. The tendency for these countries to make their own financing arrangements outside the Fund, except in extremis, was reinforced by changes in the Fund's operations which limited its ability to accommodate potential drawings by these members. The establishment of new lending facilities, the liberalization of existing ones, higher access limits, and a rush of developing country borrowers combined to place serious strains on the Fund's resources throughout the 1970s. The strains would have been considerably greater if the Group of Ten participants had used the Fund's resources as frequently as they had in the second half of the 1960s.

The third, more general reason was the reluctance of the most powerful industrial countries to take on new international commitments at a time when their own economies were making the difficult, often painful adjustment to rising inflationary pressures, higher oil prices, and deeprooted structural imbalances. This more inward-looking approach and the

\footnotetext{
${ }^{79}$ See Section III.
} 
preoccupation with immediate domestic concerns were not confined to the major industrial countries, nor were the General Arrangements the only casualty. In the 1970s, international monetary cooperation was limited mainly to short-term crisis management. The Fund was able to establish new facilities to deal with specific problems and to borrow, temporarily, from surplus countries. But Fund quotas lagged seriously behind the growth of world trade and the rapid increase in capital movements. The SDR - which was supposed to develop into an important, internationally controlled reserve asset-finished the decade as a relatively minor supplement to members' reserves. Similarly, discussions within the Fund on devising a more orderly set of exchange rate arrangements for the major currencies made very little progress. ${ }^{80}$

In retrospect, therefore, the political will which had been vital in establishing the GAB was in rather short supply among the major industrial countries. However, the General Arrangements were still in existence. They remained potentially valuable, and the pressures for reform were building up. In 1982, these various strands came together.

\section{Reform 1982-83}

It took a crisis to establish the General Arrangements to Borrow. It took another crisis to persuade the participants to change them. On both occasions, Fund quotas were inadequate; and on both occasions, the major industrial countries were unwilling to consider large quota increases as a way of meeting the problems. Instead, in 1982, the Group of Ten agreed to major reforms of the GAB similar, in most respects, to those which they rejected in 1978. Why did this happen? What are the changes? And how will they affect the Fund and the international monetary system in the period ahead?

\section{The Reason Why}

Reform of the $\mathrm{GAB}$ was a direct response by the major industrial countries to the serious strains which emerged in the international financial system in mid-1982. In short, the debt crisis. The strains, which became apparent with the well-publicized problems of Mexico and Brazil,

\footnotetext{
${ }^{80}$ It should, however, be mentioned that the European Monetary System was established by the European Community countries in 1978.
} 
were deep-rooted. They can be traced back to the growing inflationary pressures of the late 1960 s and 1970 s, to the oil price increases of 197374 and 1979-80, and to the unexpected depth and severity of the world recession after 1980 . They can also be traced to delayed adjustment in many countries, industrial as well as developing, to the new, harsher economic conditions. Many countries, and the oil importing developing countries in particular, experienced large current account deficits which had to be financed by foreign borrowing on an unprecedented scale.

From 1973 to 1981 , the total outstanding external debt of the non-oil developing countries increased at an average annual rate of approximately 20 percent. In 1981, this debt amounted to some US\$555 billion, compared with US $\$ 336$ billion in $1978 .{ }^{81}$ The ratio of this debt to these countries' export earnings reached 120 percent in 1981 (and an estimated 137 percent in 1982). The extremely uneven geographic distribution of the debt was also significant. Much of it was concentrated among a small group of major borrowers in Latin America and Eastern Europe. The debtservice ratio for these countries was much higher than the average figure.

The bulk of the debt was owed not to official creditors, like the Fund, but to private banks, which had assumed the central role, in the 1970s, in recycling the Organization of Petroleum Exporting Countries (OPEC) surplus, in particular, and in intermediating between surplus and deficit countries, in general. In a sense, this role was a natural one. It was widely applauded at the time. On the one hand, the oil producers with structural surpluses, whose absorptive capacity was limited, needed a wellestablished commercial outlet for their surpluses that would enable them to make short-to-medium-term investments. On the other hand, the financing requirements of the (mainly oil importing) deficit countries far exceeded the amounts available from official aid, trade credits, and project finance, as well as from the regional and international financial institutions.

From the banks' standpoint, country lending was more profitable than domestic lending. It provided new avenues for growth and expansion when loan demand in the industrial countries was depressed by recession and corporate failures. It looked reasonably safe in the light of historical experience with international loan losses up to 1975 . The few reschedulings that had occurred had been handled smoothly. As importantly, the

${ }^{81}$ International Monetary Fund, Annual Report (1983), p. 30. 
overwhelming proportion of new lending, notably by U.S. banks, went to supposedly healthy countries, like Mexico and Brazil, with impressive growth records and favorable export prospects. The banks were in a highly competitive market and were relying, in several cases, on out-ofdate or inadequate information about the countries concerned. In the late 1970 s, they assumed, as did most official forecasters, that global recession would be short-lived; that inflation would remain high, reducing the real value of the debt to be repaid; and that commodity prices would resume their upward trend, allowing country borrowers sufficient margin to repay.

After 1980, these assumptions were shown to be false. The world recession intensified in 1981 and 1982. The major industrial countries, notably the United States, moved decisively to monetary restraint, which was designed to break the upward trend in inflation and inflationary expectations in their economies. The result was slow growth, weak import demand, and very high interest rates for foreign as well as domestic borrowers. Protectionist pressures increased, and the volume of world trade actually fell, by $2 \frac{1}{2}$ percent, in 1982 .

For the borrowing countries, this meant growing strains on both their current and capital accounts. Commodity prices remained low and export markets weak. At the same time, high interest rates generated large and unexpected additions to debt-servicing costs, on outstanding as well as new borrowing, since much of the banks' lending was at floating rates of interest. Major borrowers, like Mexico and Brazil, were forced to rely increasingly on more expensive short-term loans; but this simply worsened the vicious circle of rising debt-service payments and additional borrowing needs, concentrated within a very short period.

For the banks and bank supervisors, levels of debt previously regarded as manageable came to be seen as large in relation to export receipts, present and prospective, and large in real terms. The need to tighten lending standards, avoid overconcentration of country loans, and improve the information base for country lending became increasingly apparent. The concerns of bank supervisors about country exposure were reinforced by the general decline in bank capital ratios since the mid-1970s and by the rise in potential losses on domestic, as well as foreign, loans.

In the summer of 1982, the banks called a halt. First Mexico, and then Brazil, were unable to obtain new, or to roll over existing, loans. The sudden realization that the two largest borrowers were in trouble prompted 


\section{THE GENERAL ARRANGEMENTS TO BORROW}

an immediate reappraisal of country risk by most banks. The result was higher spreads for virtually all country borrowers, irrespective of their particular circumstances, and an abrupt reduction in the availability of credit for specific countries. Lending to countries in "high-risk" regions, like Latin America, virtually stopped. Some banks, particularly the smaller regional banks in the United States and Europe, wanted to get out of country lending altogether. The confidence which had underpinned the financing flows of the 1970 s was seriously threatened. There were real fears that trade and capital flows would contract further, leading to default by one or more country borrowers.

\section{The Response}

The immediate crisis was averted by a series of ad hoc rescue packages involving the BIS, central banks, governments, the commercial banks, and - crucially - the Fund. The central element in these packages, then and subsequently, was an adjustment program approved by the Fund that was aimed at achieving a viable balance of payments and debt-service position over the medium term. The Fund was the only international institution which could combine financing and adjustment. It was the only institution whose "seal of approval" could serve as a catalyst in prompting other lenders, private and official, to provide the new money required for meeting immediate repayment obligations, in the short run, and for undertaking orderly adjustment, with growth, in the longer run.

But the debt crisis, and the consequent increase in requests for Fund support on a large scale, highlighted the inadequacy of Fund resources. Despite two general quota increases in 1977 (32.5 percent) and 1980 (50 percent) which raised total quotas to SDR 61 billion, the Fund's ordinary resources from quota subscriptions had not kept pace with either the growth in world trade and capital flows or with the growing needs of deficit members for balance of payments assistance. The two quota increases were political compromises which provided only limited additions to the Fund's stock of lendable resources, which were rapidly used, particularly from 1980 onward.

The Fund had therefore supplemented its resources by sizable borrowing from surplus members, first under the 1977 supplementary financing facility (SDR 7.8 billion) and then under the 1981 enlarged access agreements with Saudi Arabia and other lenders (SDR 9.3 billion). This had allowed the Fund to lend substantially more (in terms of a member's 
quota), for longer periods, to an increasing number of countries at a time of prolonged recession. It also meant that the Fund had the means available to deal with the immediate crisis of confidence in mid-1982.

However, the applications for large loans by Mexico and Brazil and the queue of further applications by other heavily indebted countries put the Fund's liquidity under serious pressure. In 1982 and early 1983, disbursements and commitments by the Fund rose to record levels, not only under stand-by and extended arrangements but also under the less conditional special facilities. By late 1982, the Fund was running down ordinary resources and overcommitting its borrowed resources.

The obvious solution-namely, a further large general increase in quotas - was already under discussion within the Fund when the debt crisis emerged. But the discussions had failed to narrow the widely divergent views of members on the Fund's role in the 1980s and on its appropriate size. On the one hand, some countries, particularly the developing countries, supported a doubling, or even a tripling, of quotas in line with the rapid increase in members' financing needs. On the other hand, major creditors, such as the United States and the Federal Republic of Germany, supported a much smaller increase of 25 percent or-at the very most - between 40 and 50 percent, which they regarded as sufficient to meet members' needs in normal circumstances and consistent with the Fund's role as a lender of last resort. The quota review was also complicated, on this occasion, by the always controversial question of adjusting members' quota shares to reflect changes in their relative economic positions.

The debt crisis gave new urgency to the quota review. It persuaded the major creditors to think again and to examine other ways of increasing Fund resources. As in all important Fund decisions, the attitude of the United States was crucial. The United States had close political and economic ties with Mexico, Brazil, Argentina, Peru, and other heavily indebted Latin American countries. ${ }^{82}$ U.S. banks were deeply involved in financing these countries' development projects, trade flows, and balance of payments deficits. The threat to the stability of the international financial system posed by the debt crisis was therefore a threat to the U.S.

${ }^{82}$ One political factor which may have been a consideration at the time was the differing attitudes of the United States and certain Latin American countries toward the South Atlantic crisis in May 1982. 
banking system, to U.S. export markets, and to employment in U.S. export industries.

It was against this background that U.S. Treasury Secretary Donald Regan proposed, at the Annual Meetings of the Fund and the World Bank in Toronto in September 1982, that an "adequate" Fund quota increase, sufficient to cover members' needs for temporary financing in normal circumstances, should be supplemented by "an additional permanent borrowing arrangement, which would be available to the IMF on a contingency basis for use in extraordinary circumstances." 83 The reform and enlargement of the GAB stemmed directly from this proposal.

From the standpoint of the United States and other major industrial countries, the proposal for a "crisis fund," either separate from, or incorporated into, the GAB, had several advantages over the alternative of a large general increase in Fund quotas. First, a crisis fund would provide the Fund with more effectively usable resources than a quota increase of comparable size. ${ }^{84}$ It would also give the Fund immediate recourse to credit lines from countries in relatively strong external positions. The bulk of these credit lines would be usable in an emergency.

Second, the establishment of a crisis fund would demonstrate to the international financial community that the Fund was in a position to deal with severe threats to the system. This, in turn, it was argued, would provide private banks and official creditors with sufficient confidence to ensure that they would continue lending to countries in difficulty. It could also reduce the risk that problems in one country would spill over into other countries.

Third, creditors of the crisis fund would have an important voice in decisions on its activation, more so than they have in decisions on lending the Fund's ordinary (quota) resources, which require only a simple majority in the Executive Board. Creditors could ensure that the Fund would borrow from the crisis fund only when the stability of the system was in jeopardy and only to finance strong adjustment programs in the borrowing countries. This was a particularly important selling point for

${ }^{83}$ Statement by Donald T. Regan, Governor of the Fund and the Bank for the United States, to the Fund/Bank Annual Meetings in Toronto, Canada at the Second Joint Session on September 6, 1982. See International Monetary Fund, Summary Proceedings (1982), p. 51 .

${ }^{84}$ As a rough guide, only about half of the resources from a general quota increase is provided by countries which are sufficiently strong to lend their currencies to the Fund. 
the United States in getting congressional approval for new money to finance the Fund.

Secretary Regan's proposal did not refer specifically to the GAB, leaving open the possibility that lenders to the crisis fund could include countries that were not Group of Ten participants. However, the General Arrangements offered a ready-made and well-tried framework for the proposal. It was quicker and easier for the Group of Ten to adapt the GAB than to start afresh with a new fund. The General Arrangements already incorporated the principal features, and the underlying philosophy, of the proposal. It is worth noting, in this regard, that the reform of the GAB left intact the separate consultative provisions of the Baumgartner letter.

Reform and enlargement of the GAB were, however, controversial. Such plans were disliked by several Fund members, and certain developing countries in particular, precisely for the reasons they were favored by the major industrial countries. They were seen as a substitute for a substantial quota increase, a substitute which would deprive the developing countries of influence and voting power in the Fund, and reduce the amounts they could borrow under the Fund's regular policies. The quota increase of 47.5 percent (to SDR 90 billion) agreed in February 1983 , shortly after the Group of Ten formally decided to enlarge the $\mathrm{GAB}$, was felt by these countries to be completely inadequate.

As in the past, the developing countries also resented the effective veto of one small group of Fund members over a major source of the Fund's financing. It was, in their view, inconsistent with the cooperative character of the Fund for an exclusive club of wealthy members to decide whether the Fund was short of liquidity and whether there was a threat to the system. These countries were also concerned that access to the enlarged GAB would not be uniform for all Fund members. (This issue is discussed later on.) It would be fair to say, as in 1962, that the Executive Board was "not enthralled" by the new-look GAB.

\section{The Changes}

The changes to the GAB decision - agreed by the Group of Ten and by the Executive Board in January and February 1983. respectively - became effective on December 26, 1983. They are fundamental. The main changes are as follows:

\section{a. Overall Size}

The total of individual credit lines under the GAB has been increased to SDR 17 billion. This was within the range of SDR 15-20 billion 


\section{THE GENERAL ARRANGEMENTS TO BORROW}

envisaged in the original U.S. proposal for a crisis fund. Some members of the Group of Ten were prepared to support a figure at the top end of this range, particularly as past experience suggested that it would be very difficult to increase the GAB again soon. Other members were, however, more conservative. The United States, in particular, was constrained by what the Congress could accept. As in 1962, the final figure was a political compromise.

\section{b. Individual Credit Lines}

The shares of individual participants in the increased total have been rearranged to reflect the changes in their economic and financial positions since 1962 and their ability to provide resources to the Fund. The new shares are shown in Table 4 .

Table 4. Enlarged Gab: Individual Credit Arrangements

\begin{tabular}{lrrr}
\hline \multicolumn{1}{c}{ Participant } & $\begin{array}{c}\text { Amount } \\
\text { (millions } \\
\text { of SDRs) }\end{array}$ & $\begin{array}{c}\text { Percentage } \\
\text { Share }\end{array}$ & $\begin{array}{c}\text { Original } \\
\text { Percentage } \\
\text { Share }\end{array}$ \\
\hline United States & $4,250.0$ & 25.00 & 33.33 \\
Deutsche Bundesbank & $2,380.0$ & 14.00 & 16.66 \\
Japan & $2,125.0$ & 12.50 & 4.16 \\
France & $1,700.0$ & 10.00 & 9.16 \\
United Kingdom & $1,700.0$ & 10.00 & 16.66 \\
Italy & $1,105.0$ & 6.50 & 9.16 \\
Canada & 892.5 & 5.25 & 3.36 \\
Netherlands & 850.0 & 5.00 & 3.36 \\
Belgium & 595.0 & 3.50 & 2.50 \\
Sveriges Riksbank & 382.5 & 2.25 & 1.66 \\
Swiss National Bank & $1,020.0$ & 6.00 & - \\
\multicolumn{1}{c}{ Total } & $17,000.0$ & 100.00 & 100.00 \\
\hline
\end{tabular}

As in 1962, the size of the individual credit lines was decided rather informally. There was no single or precise formula. A number of broad indicators were taken into account, such as gross domestic product, nongold reserves, the calculations used in the most recent Fund quota review, and the relative contributions of participants to the 1977 supplementary financing facility. But it was just as much a question of working backward from an agreed total to accommodate the preferences and constraints of 
individual participants. The United States, for example, was prepared to provide one quarter of the total; and it was clear that the credit lines of the Deutsche Bundesbank and Japan should be the second and third largest, respectively. Other changes in relative positions were fairly minor. As in the past, the individual amounts may be reviewed periodically "in the light of developing circumstances" and changed with the agreement of the Fund and all participants. ${ }^{85}$

In a related change, it was also decided to raise the minimum amount of a credit arrangement for new participants. Originally set at the equivalent of US\$100 million (and subsequently SDR 100 million), the current minimum, expressed in SDRs, is "not . . less than the amount of the credit arrangement of the participant with the smallest credit arrangement." ${ }^{86}$ At present, the Sveriges Riksbank has the smallest arrangement, for the equivalent of SDR 382.5 million (Table 4).

\section{c. Participation of Switzerland}

As shown in Table 4, Switzerland has become a participant-through the Swiss National Bank-in the GAB ${ }^{87}$ The change from the previous associated status reflects, inter alia, Switzerland's wish to become a more equal member of the Group of Ten "club." The credit line of the Swiss National Bank has been increased significantly, to SDR 1,020 million, in line with Switzerland's economic and financial strength relative to the other participants. As in the past, the fact that Switzerland is not a member of the Fund means that the Fund cannot call on the revised GAB to finance transactions with Switzerland, except to make early repayment of claims held by the Swiss National Bank in case of balance of payments and reserve need.

\section{d. Associated Borrowing Arrangements}

The revised GAB decision allows the Fund to enter, in association with the $\mathrm{GAB},{ }^{88}$ into borrowing arrangements with members which are not

\footnotetext{
${ }^{85}$ See Paragraph 5 of Executive Board Decision No. 7337-(83/37), February 24, 1983, in Selected Decisions, 10th (1983), p. 133.

${ }^{86}$ Ibid., Paragraph 3, pp. 132-33.

${ }^{87}$ Switzerland formally adhered to the enlarged GAB in April 1984 after completion of the necessary domestic legislative procedures.

${ }^{88}$ See Paragraph 23 of Executive Board Decision No. 7337-(83/37), February 24. 1983. in Selected Decisions, 10th (1983), p. 144.
} 


\section{THE GENERAL ARRANGEMENTS TO BORROW}

GAB participants. The form of association with the GAB may take one of several forms. It could be very close. The Fund could, for example, conclude a borrowing arrangement with a nonparticipant on terms very similar to those that apply to GAB participants. With the consent of the GAB participants, such an arrangement could authorize the Fund to call on the $\mathrm{GAB}$ to finance transactions with the nonparticipant member, and to refinance claims of the nonparticipant which were encashed prior to maturity on balance of payments and reserve grounds. In this case, a nonparticipant would have virtually the same rights and responsibilities as a GAB participant.

Alternatively, the form of association between the nonparticipant and the GAB could be looser. For example, the Fund could agree a borrowing arrangement with a nonparticipant, for purposes similar to those of the General Arrangements and on comparable terms, but the Fund would not be able to call on the GAB to finance transactions with the nonparticipant or to refinance the nonparticipant's claims if they were encashed prior to maturity. The precise form of the relationship with the GAB would be agreed separately between the nonparticipant and the GAB participants.

Finally, there is nothing in the revised decision to prevent the Fund from making other borrowing arrangements for purposes and on terms unrelated to the GAB.

\section{e. Associated Arrangement with Saudi Arabia}

The Fund has already concluded one associated borrowing arrangement, with Saudi Arabia, which became effective in December 1983 when the revised General Arrangements entered into force. ${ }^{89}$ Under the arrangement, Saudi Arabia will stand ready to lend the Fund up to SDR 1.5 billion on a revolving basis over five years, to assist in financing drawings by members for the same purposes and in the same circumstances as are prescribed in the revised GAB decision. The procedure for making calls, the interest rate, and most other terms and conditions are essentially the same as those in the revised GAB.

But the arrangement with Saudi Arabia is set apart from the GAB in three important ways. First, the Fund is not authorized to call on the GAB

\footnotetext{
${ }^{89}$ See Executive Board Decision No. 7403-(83/73), May 20, 1983, in International Monetary Fund, Annual Report of the Executive Board for the Financial Year Ended April 30, 1983 (1983), pp. 154-57.
} 
to finance transactions with Saudi Arabia. Saudi Arabia is therefore assuming responsibilities similar to those of the $\mathrm{GAB}$ participants but without similar potential benefits. On the other hand, Saudi Arabia is free to accept or reject any proposal by the Managing Director. In this respect, Saudi Arabia has more flexibility than the individual GAB participants, each of which is bound, under the procedures in the Baumgartner letter, to implement a proposal once it is accepted by the participants as a group. ${ }^{90}$ Third, the General Arrangements and the arrangement with Saudi Arabia may be activated separately. The Managing Director of the Fund is not legally required to propose a call on Saudi Arabia each time one is proposed to the GAB participants, nor is he required to propose a call to GAB participants each time one is proposed to Saudi Arabia.

The arrangement with Saudi Arabia does not refer specifically to the relationship between Saudi Arabia and GAB participants, which is covered in separate, informal understandings. But there is provision in the arrangement for converting it, at some future date, into a form more closely associated with the GAB and for the possibility that Saudi Arabia could become a participant in the GAB. The initiative for such changes would come from Saudi Arabia and would have to be accepted by both the Fund and the GAB participants.

\section{f. Use of the GAB for the Benefit of Nonparticipants}

The revised GAB decision allows the Fund, for the first time, to call on the participants to finance drawings by nonparticipants. But the Fund can do so only in certain well-defined circumstances. ${ }^{91}$

First, such drawings must be made in support of adjustment programs. Drawings on the Fund by nonparticipants in the (unconditional) reserve tranche; under the special facilities, such as the compensatory financing facility; or in the first credit tranche and not linked with a stand-by or extended arrangement will not be eligible for financing under the GAB. These requirements are more restrictive than those for drawings by GAB participants, since the Fund will continue to be able to call on the GAB to finance unconditional exchange transactions with the Group of Ten.

Second, special criteria must be met before the Managing Director may

\footnotetext{
${ }^{90}$ See Section III.

${ }^{91}$ See Paragraph 21 of Executive Board Decision No. 7337-(83/37), February 24, 1983. in Selected Decisions, 10th (1983), p. 142.
} 


\section{THE GENERAL ARRANGEMENTS TO BORROW}

propose calls on the $\mathrm{GAB}$ to finance transactions with nonparticipants. The Managing Director must be satisfied after "consultation," which will clearly involve the $\mathrm{GAB}$ participants, that

the Fund faces an inadequacy of resources to meet actual and expected requests for financing that reflect the existence of an exceptional situation associated with balance of payments problems of members of a character or aggregate size that could threaten the stability of the international monetary system. ${ }^{92}$

Again, these criteria are stricter than those for participants. In particular, the criterion referring to problems which could "threaten" the system is more severe than the language of the original and revised preambles, which allow the General Arrangements to be activated for the benefit of participants to forestall or cope with an "impairment" of the system. ${ }^{93}$ This is not necessarily a matter of semantics. "Impairment," implying damage but not destruction, was preferred to "threat," which suggested the risk of collapse, in the 1961-62 discussions precisely because the latter was considered too severe. ${ }^{94}$

Third, in making such calls, the Managing Director is also required to pay due regard to potential calls on the GAB for the benefit of the participants. This does not imply that a specified amount of GAB resources should, or will be, set aside to finance possible requests by participants. But it serves notice of the continued importance which the participants attach to the GAB's original purpose.

On the surface, these three conditions are, to say the least, restrictive. In part, this is because the potential benefits for nonparticipants are not matched by any reciprocal commitment to lend to the Fund. ${ }^{95}$ However, to counterbalance this apparent stringency and to take account of some of the criticisms made by nonparticipants, the GAB decision has also been amended to make it absolutely clear that the revision and enlargement of the GAB does not affect the Fund's authority to deal with requests for drawings by individual members. The decision specifically states that access to Fund resources will continue to depend on established policies and practices and not simply on whether the Fund is able to borrow from

\footnotetext{
${ }^{92}$ Ibid.

${ }^{93}$ Ibid., p. 117. See also Section III of this pamphlet.

${ }^{94}$ See Gold (1984), Vol. 2, Chap. 6, pp. 486, 501. I am indebted to Gold for explaining this important point to me.

95 Ibid., p. 502.
} 
the GAB. ${ }^{96}$ If, for example, the GAB participants are not prepared to lend at any particular time, the Fund can try to borrow from other sources.

\section{g. Other Changes}

As often happens when a long-overdue reform takes place, the opportunity was also taken to update various provisions and to bring the GAB more into line with the Fund's more recent borrowing agreements.

Interest Rate. GAB creditors should now have no cause to complain, as they did in $1978,{ }^{97}$ that the interest rate is too low. The interest rate on GAB loans will no longer be linked to the charges levied by the Fund on the drawings financed by GAB borrowing. It will now be market related, as it is, for example, under the borrowing agreements to finance the enlarged access policy. GAB creditors will earn interest at a rate equal to the combined market interest rate calculated by the Fund to determine the rate at which it pays interest on holdings of SDRs. At present, the combined market interest rate is determined on the basis of a weighted average of yields on short-term market instruments denominated in the five currencies that make up the SDR basket. The revised decision also protects $\mathrm{GAB}$ creditors against the possibility of a change in the Fund's method of calculating the combined interest rate. ${ }^{98}$ Interest will accrue daily and be payable quarterly in SDRs, in the participant's currency, or in other actually convertible currencies. At the same time, the $1 / 2$ of 1 percent transfer charge payable by the Fund on GAB loans has been abolished.

Denomination. It has also been agreed to denominate the individual credit lines in SDRs. This will avoid unintended changes in their value, caused by exchange rate fluctuations. The participants' change of heart on this question can perhaps be traced to the large, and sometimes erratic, swings in the exchange rates of the major currencies since 1978, when a

\footnotetext{
${ }^{96}$ See Paragraph 10 of Executive Board Decision No. 7337-(83/37), February 24, 1983, in Selected Decisions, 10th (1983), p. 136.

${ }^{97}$ See Section III.

${ }^{98}$ See Paragraph 9 of Executive Board Decision No. 7337-(83/37), February 24, 1983, in Selected Decisions, 10th (1983), pp. 135-36. The paragraph provides, inter alia, that a change in the method of calculating the combined rate will apply to GAB loans (both outstanding and subsequently provided) only with the agreement of the Fund and "at least two thirds of the participants having three fifths of the total amount of the credit arrangements," with the further caveat that a GAB creditor may choose, at the time such agreement is reached, not to have the new method applied to its outstanding GAB claims.
} 


\section{THE GENERAL ARRANGEMENTS TO BORROW}

shift to SDR denomination was rejected. ${ }^{99}$ The SDR is now fully established as the unit of account for the General Arrangements. With the exception of Switzerland, however, participants will continue to make loans to the Fund in their own currencies. The Swiss National Bank will lend "freely usable" currency agreed with the Fund, since the Fund cannot borrow a nonmember's currency. ${ }^{100}$

Repayment. The repayment provisions of the GAB were designed, inter alia, to ensure that the Fund would repay GAB creditors as and when the GAB beneficiary repaid the corresponding drawing to the Fund, with a maximum repayment period of five years. ${ }^{101}$ The provisions did not, however, fully cover reserve-tranche drawings by participants after the Second Amendment of the Articles of Agreement in April 1978. Such drawings no longer had to be repaid to the Fund; but the Fund could subsequently sell the currency of the drawer to finance transactions with other members. The effect, of restoring the drawer's reserve-tranche position in the Fund, was equivalent to repayment (if repayment had been possible).

This happened in the case of the U.S. reserve-tranche drawing in November 1978, which was financed in part by calls on the GAB. The United States was not legally obliged to repay this drawing; the Fund therefore repaid the two GAB creditors, the Deutsche Bundesbank and Japan, after the maximum repayment period of five years had elapsed. In practice, however, the Fund sold large amounts of U.S. dollars from 1979 onward which restored the U.S. reserve-tranche position in the Fund. But the Fund incurred no corresponding obligation to repay the Deutsche Bundesbank and Japan any sooner. This was unfair to the Federal Republic of Germany and Japan, particularly since the United States was receiving remuneration from the Fund on its restored reserve-tranche position at a higher rate than the two GAB creditors were earning on their outstanding loans. This anomaly has therefore been corrected in the revised $\mathrm{GAB}$ decision. ${ }^{102}$

\footnotetext{
${ }^{99}$ See Section IV.

${ }^{100}$ Under the Fund's present practice, "freely usable" currencies are the U.S. dollar, the pound sterling, the deutsche mark, the French franc, and the yen.

${ }^{101}$ See Section III.

${ }^{102}$ Paragraph 11 (c) of the revised decision states, inter alia, that: If the Fund is indebted to a participant as a result of transfers to finance a reserve tranche purchase by a drawer and the Fund's holdings of the drawer's currency that
} 
Transferability. As explained earlier, the formal provisions on transferability in the original GAB decision were supplemented by an Executive Board decision in March 1979. ${ }^{103}$ This decision was updated and changed in February 1984, after the revised General Arrangements became effective. The new decision provides that GAB claims may be transferred to the Swiss National Bank (now a participant) on essentially the same conditions as transfers to other participants. More significantly, the decision further broadens the scope for transfers of GAB claims among the participants, in line with the corresponding provisions in the Fund's more recent borrowing agreements. The decision ensures that $\mathrm{GAB}$ claims will continue to be highly liquid assets which participants can mobilize in a crisis. ${ }^{104}$

In a separate, but related, decision, also taken in February 1984, Saudi Arabia was given considerable freedom to transfer its claims under the associated borrowing arrangement. ${ }^{105}$ Unlike GAB claims, which may only be transferred among the participants, Saudi Arabia may transfer its claims to any Fund member. This is a further example of the distinction between the GAB "proper" and the looser form of associated arrangement agreed with Saudi Arabia. ${ }^{106}$

Tidying Up. The revised GAB decision also incorporates a number of other changes, mainly of a technical or tidying-up nature. For example,

are not subject to repurchase are reduced as a result of net sales of that currency during a quarterly period covered by an operational budget, the Fund shall repay at the beginning of the next quarterly period an amount equivalent to that reduction, up to the amount of the indebtedness to the participant.

Executive Board Decision No. 7337-(83/37), February 24, 1983, in Selected Decisions, 10th (1983), p. 137.

${ }^{103}$ See Section III.

${ }^{104}$ See Executive Board Decision No. 7628-(84/25), February 15, 1984, effective April 10, 1984, in International Monetary Fund, Annual Report (1984), pp. 139-40. As in the past, a participant will be able to transfer a GAB claim at any time to another participant, but the previous requirement that the transferee should be a net Fund creditor has been dropped. The sole requirement, to protect the Fund's liquidity, is that the transferee will acquire the right of early encashment of the transferred claim on balance of payments grounds only if, at the time of the transfer, its external position is sufficiently strong for its currency to be usable by the Fund in net sales in the operational budget.

${ }^{105}$ See Executive Board Decision No. 7629-(84/25), February 15, 1984, effective April 10, 1984, in International Monetary Fund, Annual Report of the Executive Board for the Financial Year Ended April 30, 1984 (1984), pp. 140-41.

${ }^{106}$ See subsections (d) and (e)- "Associated Borrowing Arrangements" and "Associated Arrangement with Saudi Arabia," respectively. 


\section{THE GENERAL ARRANGEMENTS TO BORROW}

the amended Preamble retains the same broad description of the circumstances in which the GAB may be activated-namely, when supplementary resources are needed to forestall or cope with an impairment of the international monetary system, but the (now redundant) references to the "new conditions" of widespread convertibility and greater freedom for short-term capital movements have been dropped. ${ }^{107}$ The debt problems of 1982-83 showed, very clearly, that the Fund might need to call on the General Arrangements if the system were being impaired for other reasons.

Similarly, all references to stand-by arrangements have been expanded to include extended arrangements, which did not exist in 1962. The Fund will now be able to make calls on the GAB to finance both types of arrangement with participants and nonparticipants alike.

\section{h. Period of Renewal and Review}

Finally, the revised General Arrangements will remain in force for five years from December 1983. The functioning of the revised GAB, and in particular the use of the GAB for the benefit of nonparticipants, will be reviewed by the Fund and the GAB participants when they are considering renewal of the $\mathrm{GAB}$ for any subsequent period.

\section{A Look Ahead}

The reforms of the $\mathrm{GAB}$ were long overdue. They do much to restore the General Arrangements to their original relative importance as a valuable line of defense for the Fund. It is, however, not easy to assess how this line of defense will operate or how readily it will be available to the Fund in a crisis.

On the one hand, the reforms strengthen the Fund in several important ways. First, the tripling of the GAB, together with the quota increase that emerged from the Eighth General Review of Quotas and the further SDR 6 billion loan from the BIS, the National Bank of Belgium, Japan, and Saudi Arabia ${ }^{108}$ represent major additions to the Fund's resource base. The Fund is now in a much more secure financial position. Taken

\footnotetext{
${ }^{107}$ See Section III.

${ }^{108}$ This loan, which was agreed in April 1984, is designed to cover the Fund's commitments of borrowed resources under the enlarged access policy.
} 
together, the enlarged General Arrangements and the quota increase should give the Fund access to new usable resources of about SDR 23 billion ${ }^{109}$ until the next quota review is completed, probably in 1988. These are substantial amounts. The fact that such amounts are there should give the private banks and official creditors confidence in the Fund's ability to deal with future problems in the international monetary system. Even if the enlarged General Arrangements are not used, they should serve to enhance the Fund's authority and standing in the period ahead.

Second, and more directly, the Fund is in a position to continue assisting its members on an adequate scale. The enlarged access policy has been continued in 1984, and will be continued in 1985, albeit with maximum access limits which are progressively lower, in terms of quota, than the limits that applied in 1981-83. ${ }^{110}$ The Fund should, therefore, remain an effective agent for adjustment and an important catalyst for other financial flows. Without the quota increase, the SDR 6 billion loan, and the backing of the enlarged $\mathrm{GAB}$, the enlarged access policy would have had to be abruptly curtailed.

Third, the enlargement of the GAB means that the Fund is now in a better position to meet potential borrowing needs of the main industrial countries. Although none of these countries has come to the Fund since 1978 , such an approach cannot be ruled out, particularly if the economic recovery falters in Europe. Without the enlarged GAB, drawings by industrial countries might have put considerable strain on Fund resources.

${ }^{109}$ The figure of SDR 23 billion in new usable resources is based on the Fund's working assumption that half of the quota increase (SDR 15 billion) and two thirds of the increase in the GAB and the associated arrangement with Saudi Arabia (SDR 8 billion) will be available for on-lending by the Fund.

${ }^{110}$ From 1981-83, the Fund's guidelines for drawings under the enlarged access policy provided for annual access of up to 150 percent of quota; up to 450 percent over three years; and cumulative access up to 600 percent, excluding special facilities and scheduled repurchases. In 1984, these limits were replaced by a two-tier system of access, agreed by the Interim Committee in September 1983, providing for maximum annual limits of 102 or 125 percent of quota; three-year limits of 306 or 375 percent; and cumulative limits of 408 or 500 percent, depending on the seriousness of members' balance of payments needs and the strength of their adjustment efforts. In 1985, the maximum limits will be further reduced, following agreement by the Interim Committee in September 1984, to 95 or 115 percent annually; 280 or 345 percent over three years; and 408 or 450 percent for cumulative access, again depending on members' balance of payments needs and on their adjustment efforts. The Fund, however, retains the flexibility to allow access above the agreed limits in exceptional circumstances. 
The risk of the Fund becoming simply a bank for developing countries, contrary to the purposes of the Articles of Agreement, is now much less.

Fourth, the General Arrangements have now become more open and less exclusive. The fact that the Fund will be able to tap the GAB for onlending to nonparticipants is potentially very significant. Virtually all of the Fund's conditional lending in recent years has been to the developing countries. It is also likely that this group of countries will rely heavily on the Fund's financial support in the period ahead.

The Fund's access to the GAB to meet developing countries' borrowing needs is, of course, highly conditional. The Fund must be short of liquidity, and the stability of the system must be threatened, not simply impaired. ${ }^{111}$ But the conditions for activating the GAB have been interpreted flexibly in the past. A threat to the system could, for example, cover a number of possibilities, ranging from serious problems in one large country, such as Brazil, to actual or potential problems in a group of small countries or in a specific region. It is also important that no fixed amount has been set aside for use by participants. It is, therefore, possible that access to the GAB for the benefit of nonparticipants could be sizable.

Fifth, the Fund's liquidity could be considerably strengthened in the future if the Group of Ten is now prepared to admit outsiders into their club. The participation of Switzerland sets an important precedent, as does the association of Saudi Arabia, which could eventually become a participant. There is also provision for further associated arrangements with other strong countries. Such arrangements could, similarly, be stepping-stones to participation. There could, perhaps, be candidates among the members of the OECD, particularly since there is now the attraction of a market-related interest rate on GAB claims.

On the other hand, the revised General Arrangements leave a number of questions unanswered. First, it could be argued that their overall size may be insufficient to cover potential demands on the Fund by participants as well as nonparticipants. This would, of course, be particularly true if the participants were to rule out further increases in their credit arrangements for another 20 years.

More specifically, the new total of SDR 18.5 billion (including Saudi Arabia) is equivalent to only 35 percent of participants' Fund quo-

\footnotetext{
${ }^{111}$ See Section V.
} 
tas, ${ }^{112}$ compared with 60 percent in 1962 , and to only 8 percent of their reserves at the end of $1983,{ }^{113}$ compared with 15 percent in 1962 . It is no longer true, as it was in 1963-73, that the current account balances of the original ten participants are invariably positive in aggregate. All ten of the original participants recorded current account deficits in at least two of the six years 1977-82. Some of the participants continue to have sizable current account deficits.

It is, therefore, possible that, say, two major participants could come to the Fund to borrow very large amounts when the external positions of several other participants were not very strong. In such a case, the credit lines of the prospective GAB beneficiaries would not be available for onlending, and the Fund might be able to call only limited amounts from the credit lines of some of the other participants. Bearing in mind that the Fund now has to pay due regard to potential, as well as actual, calls for the benefit of participants, this could leave very little available in the enlarged $\mathrm{GAB}$ for nonparticipants.

Second, it could be argued that the conditions for activating the GAB for nonparticipants are overly restrictive. If the 1961-62 discussions are any guide, the system may have to be in danger of collapse before such activations take place. ${ }^{114}$ The developing countries are also very concerned that the definition of a threat to the system will be made by the GAB participants and not by the Fund alone. They fear that the General Arrangements may not be activated at all for nonparticipants or, if they are, only for a large country, like Mexico or Brazil, in which the GAB creditors have important interests.

Third, the possible use of the GAB for the benefit of nonparticipants may be only temporary. The new provisions will be the subject of particular scrutiny by the participants before the General Arrangements are next renewed. If the crisis atmosphere of 1982 has given way to a more settled international outlook, the participants could decide to restore the General Arrangements to their original role as a source of finance available exclusively for drawings by the Group of Ten on the Fund.

\footnotetext{
${ }^{112}$ After the Eighth General Review of Quotas, and including Saudi Arabia. See International Monetary Fund, International Financial Statistics (Washington), various issues.

${ }^{113}$ Percentage of total reserves of participants, including Saudi Arabia and Switzerland, valued in SDRs, with gold at SDR 35 per ounce. See International Monetary Fund, International Financial Statistics (Washington), various issues.

${ }^{114}$ See Section V.
} 
Fourth, and more generally, the enlargement of the General Arrangements, in preference to a much larger quota increase, could be interpreted as a shift to a more conservative role for the Fund in the mid-1980s. The quota increase that emerged from the Eighth General Review was below what could have been justified by members' potential needs for Fund financing. The GAB participants, and not the Fund, have control over the new GAB resources. In recent months, the major industrial countries have been pressing the Fund to recognize the constraints on its resources and to live within these constraints. They have successfully urged the Fund to provide less finance over shorter periods and subject to stricter conditions. They believe that the Fund is overextended and should return to its more traditional monetary role as a temporary lender of last resort.

\section{Conclusion}

Despite considerable progress toward external adjustment by debtor countries in 1983 and the first half of 1984, the demand for Fund resources may remain at a historically high level, at least through 1986. The problems related to the debt crisis are deep-rooted. They can be solved only over the medium term, in the framework of a sustained world recovery, declining international interest rates, and a dismantling of protectionist barriers. Even if these favorable developments occur, many countries face a long and difficult period of adjustment. To be successful, their efforts will have to be supported by appropriate rescheduling arrangements and by adequate new finance, both from the Fund and from other creditors, encouraged by the Fund's "seal of approval."

The extent of these demands on the Fund depends on a number of unpredictable factors, the chief of which are the evolution of the world economy, the changing distribution of members' surpluses and deficits, and the availability of bank credit. If the present economic recovery becomes more widespread in 1985 and 1986; if adjustment efforts of debtor countries are sustained; and if there is renewed confidence on the part of private and official creditors, the Fund may not have to call on the GAB through 1987-88 (when the next general quota review will take place). This is possible, although not yet probable. Even if only some of these favorable developments occur, the Fund may be able to get by without the General Arrangements. As at mid-1984, the Fund's liquidity 
position was much stronger than it had been for several years. Use of Fund resources appeared to be declining from recent peaks; and the maximum limits under the enlarged access policy will be further reduced in $1985 .{ }^{115}$

On the other hand, the system remains vulnerable to a number of potential shocks. The recovery is not well established in many countries and could falter. Several important debtors are delaying much-needed adjustment measures. Trade barriers pose a real threat to developing countries' exports and debt-servicing capacities. The banks, in general, remain very cautious about providing new loans to developing countries. There could, therefore, be continuing instability, resulting in heavy demands on the Fund.

If so, the Fund may have to borrow, perhaps on a large scale, or cut back on its lending operations. If the Fund decides to borrow, there may be no realistic alternative to borrowing from the GAB. The chances of further bilateral borrowing from official sources are slim, and market borrowing by the Fund is, at present, opposed by several influential Fund members.

Whether the funds at the disposal of the GAB participants would be readily available to the Fund in such circumstances is a question that cannot be answered precisely in advance. But the indications are that the major participants would be cautious about possible activations for nonparticipants. Their conservative philosophy has already had a considerable impact on Fund policies in 1983 and 1984. Their belief that the enlarged access policy should be phased out completely by 1987 or 1988 is reflected in the successive reductions in access limits. The criteria for access in individual cases are being interpreted more strictly. There has been a marked shift away from three-year extended arrangements to oneyear stand-by arrangements. Access to the special facilities has been reduced, in terms of quota, in 1984 (although it will stay the same in 1985); and use of the compensatory financing facility has become more conditional. It is also more likely that the charges for borrowing members will continue to rise following the decision in January 1984 to bring the rate of remuneration, which the Fund pays creditors for use of their quota subscriptions, closer to market levels.

At this stage, therefore, it seems likely that the General Arrangements will be available later rather than sooner, and then only in a real

${ }^{115}$ See Section VI. 
emergency. This is not reassuring to developing countries, particularly since they will not make the decision. Similarly, the Fund cannot know in precisely what circumstances it may call on the General Arrangements, which creates an element of uncertainty in the Fund's resource planning.

The Fund has, however, lived with such political constraints in the past. More importantly, the radical reform of the GAB, after 20 years of inertia, shows that the major countries are prepared to support the Fund in a crisis. The Fund now has access to a substantial reserve. Whatever their drawbacks, the reformed General Arrangements should help to foster stability and confidence in the system in the period ahead. 


\section{APPENDICES}

\section{General Arrangements to Borrow: Original Decision}

\section{Preamble}

In order to enable the International Monetary Fund to fulfill more effectively its role in the international monetary system in the new conditions of widespread convertibility, including greater freedom for short-term capital movements, the main industrial countries have agreed that they will, in a spirit of broad and willing cooperation, strengthen the Fund by general arrangements under which they will stand ready to lend their currencies to the Fund up to specified amounts under Article VII, Section 2 of the Articles of Agreement when supplementary resources are needed to forestall or cope with an impairment of the international monetary system in the aforesaid conditions. In order to give effect to these intentions, the following terms and conditions are adopted under Article VII, Section 2 of the Articles of Agreement.

\section{Paragraph 1. Definitions}

As used in this Decision the term:

(i) "Articles" means the Articles of Agreement of the International Monetary Fund;

(ii) "credit arrangement" means an undertaking to lend to the Fund on the terms and conditions of this Decision;

(iii) "participant" means a participating member or a participating institution;

(iv) "participating institution" means an official institution of a member that has entered into a credit arrangement with the Fund with the consent of the member;

(v) "participating member" means a member of the Fund that has entered into a credit arrangement with the Fund;

(vi) "amount of a credit arrangement" means the maximum amount expressed in units of its currency that a participant undertakes to lend to the Fund under a credit arrangement;

(vii) "call" means a notice by the Fund to a participant to make a transfer under its credit arrangement to the Fund's account;

(viii) "borrowed currency" means currency transferred to the Fund's account under a credit arrangement;

(ix) "drawer" means a member that purchases borrowed currency from the Fund in an exchange transaction or in an exchange transaction under a stand-by arrangement;

\section{CInternational Monetary Fund. Not for Redistribution}




\section{THE GENERAL ARRANGEMENTS TO BORROW}

(x) "indebtedness" of the Fund means the amount it is committed to repay under a credit arrangement.

\section{Paragraph 2. Credit Arrangements}

A member or institution that adheres to this Decision undertakes to lend its currency to the Fund on the terms and conditions of this Decision up to the amount in units of its currency set forth in the Annex to this Decision or established in accordance with Paragraph 3(b).

\section{Paragraph 3. Adherence}

(a) Any member or institution specified in the Annex may adhere to this Decision in accordance with Paragraph 3(c).

(b) Any member or institution not specified in the Annex that wishes to become a participant may at any time, after consultation with the Fund, give notice of its willingness to adhere to this Decision, and, if the Fund shall so agree and no participant object, the member or institution may adhere in accordance with Paragraph 3(c). When giving notice of its willingness to adhere under this Paragraph 3(b) a member or institution shall specify the amount, expressed in terms of its currency, of the credit arrangement which it is willing to enter into, provided that the amount shall not be less than the equivalent at the date of adherence of one hundred million United States dollars of the weight and fineness in effect on July 1, 1944.

(c) A member or institution shall adhere to this Decision by depositing with the Fund an instrument setting forth that it has adhered in accordance with its law and has taken all steps necessary to enable it to carry out the terms and conditions of this Decision. On the deposit of the instrument the member or institution shall be a participant as of the date of the deposit or of the effective date of this Decision, whichever shall be later.

\section{Paragraph 4. Entry into Force}

This Decision shall become effective when it has been adhered to by at least seven of the members or institutions included in the Annex with credit arrangements amounting in all to not less than the equivalent of five and one-half billion United States dollars of the weight and fineness in effect on July 1, 1944.

\section{Paragraph 5. Changes in Amounts of Credit Arrangements}

The amounts of participants' credit arrangements may be reviewed from time to time in the light of developing circumstances and changed with the agreement of the Fund and all participants.

\section{Paragraph 6. Initial Procedure}

When a participating member or a member whose institution is a participant approaches the Fund on an exchange transaction or stand-by arrangement and the 
Managing Director, after consultation, considers that the exchange transaction or stand-by arrangement is necessary in order to forestall or cope with an impairment of the international monetary system, and that the Fund's resources need to be supplemented for this purpose, he shall initiate the procedure for making calls under Paragraph 7.

\section{Paragraph 7. Calls}

(a) The Managing Director shall make a proposal for calls for an exchange transaction or for future calls for exchange transactions under a stand-by arrangement only after consultation with Executive Directors and participants. A proposal shall become effective only if it is accepted by participants and the proposal is then approved by the Executive Directors. Each participant shall notify the Fund of the acceptance of a proposal involving a call under its credit arrangement.

(b) The currencies and amounts to be called under one or more of the credit arrangements shall be based on the present and prospective balance of payments and reserve positions of participating members or members whose institutions are participants and on the Fund's holdings of currencies.

(c) Unless otherwise provided in a proposal for future calls approved under Paragraph 7(a), purchases of borrowed currency under a stand-by arrangement shall be made in the currencies of participants in proportion to the amounts in the proposal.

(d) If a participant on which calls may be made pursuant to Paragraph 7(a) for a drawer's purchases under a stand-by arrangement gives notice to the Fund that in the participant's opinion, based on the present and prospective balance of payments and reserve position, calls should no longer be made on the participant or that calls should be for a smaller amount, the Managing Director may propose to other participants that substitute amounts be made available under their credit arrangements, and this proposal shall be subject to the procedure of Paragraph 7(a). The proposal as originally approved under Paragraph 7(a) shall remain effective unless and until a proposal for substitute amounts is approved in accordance with Paragraph 7(a).

(e) When the Fund makes a call pursuant to this Paragraph 7, the participant shall promptly make the transfer in accordance with the call.

\section{Paragraph 8. Evidence of Indebtedness}

(a) The Fund shall issue to a participant, on its request, nonnegotiable instruments evidencing the Fund's indebtedness to the participant. The form of the instruments shall be agreed between the Fund and the participant.

(b) Upon repayment of the amount of any instrument issued under Paragraph 8(a) and all accrued interest, the instrument shall be returned to the Fund for cancellation. If less than the amount of any such instrument is repaid, the instrument shall be returned to the Fund and a new instrument for the remainder of the amount shall be substituted with the same maturity date as in the old instrument. 


\section{Paragraph 9. Interest and Charges}

(a) The Fund shall pay a charge of one-half of one per cent on transfers made in accordance with Paragraph 7(e).

(b) The Fund shall pay interest on its indebtedness at the rate of one and onehalf per cent per annum. In the event that this becomes different from a basic rate determined as follows:

the charge levied by the Fund pursuant to Article V, Section 8(a) plus the charge levied by the Fund pursuant to Article V, Section $8(c)$ (i), as changed from time to time under Article V, Section 8(e), during the first year after a purchase of exchange from the Fund, minus one-half of one per cent,

the interest payable by the Fund shall be changed by the same amount as from the date when the difference in the basic rate takes effect. Interest shall be paid as soon as possible after July 31 , October 31 , January 31 , and April 30.

(c) Interest and charges shall be paid in gold to the extent that this can be effected in bars. Any balance not so paid shall be paid in United States dollars.

(d) Gold payable to a participant in accordance with Paragraph 9(b) or Paragraph 11 shall be delivered at any gold depository of the Fund chosen by the participant at which the Fund has sufficient gold for making the payment. Such delivery shall be free of any charges or costs for the participant.

\section{Paragraph 10. Use of Borrowed Currency}

The Fund's policies and practices on the use of its resources and stand-by arrangements, including those relating to the period of use, shall apply to purchases of currency borrowed by the Fund.

\section{Paragraph 11. Repayment by the Fund}

(a) Subject to the other provisions of this Paragraph 11, the Fund, five years after a transfer by a participant, shall repay the participant an amount equivalent to the transfer calculated in accordance with Paragraph 12. If the drawer for whose purchase participants make transfers is committed to repurchase at a fixed date earlier than five years after its purchase, the Fund shall repay the participants at that date. Repayment under this Paragraph 11(a) or under Paragraph 11(c) shall be, as determined by the Fund, in the participant's currency whenever feasible, or gold, or, after consultation with the participant, in other currencies that are convertible in fact. Repayments to a participant under the subsequent provisions of this Paragraph 11 shall be credited against transfers by the participant for a drawer's purchases in the order in which repayment must be made under this Paragraph 11(a).

(b) Before the date prescribed in Paragraph 11(a), the Fund, after consultation with a participant, may make repayment to the participant, in part or in full, with any increases in the Fund's holdings of the participant's currency that exceed the Fund's working requirements, and participants shall accept such repayment. 
(c) Whenever a drawer repurchases, the Fund shall promptly repay an equivalent amount, except in any of the following cases:

(i) The repurchase is under Article V, Section 7(b) and can be identified as being in respect of a purchase of currency other than borrowed currency.

(ii) The repurchase is in discharge of a commitment entered into on a purchase of currency other than borrowed currency.

(iii) The repurchase entitles the drawer to augmented rights under a stand-by arrangement pursuant to Section II of Decision No. 876-(59/15) of the Executive Directors, provided that, to the extent that the drawer does not exercise such augmented rights, the Fund shall promptly repay an equivalent amount on the expiration of the stand-by arrangement.

(d) Whenever the Fund decides in agreement with a drawer that the problem for which the drawer made its purchases has been overcome, the drawer shall complete repurchase, and the Fund shall complete repayment and be entitled to use its holdings of the drawer's currency below 75 per cent of the drawer's quota in order to complete such repayment.

(e) Repayments under Paragraph 11(c) and (d) shall be made in the order established under Paragraph 11(a) and in proportion to the Fund's indebtedness to the participants that made transfers in respect of which repayment is being made.

(f) Before the date prescribed in Paragraph 11(a) a participant may give notice representing that there is a balance of payments need for repayment of part or all of the Fund's indebtedness and requesting such repayment. The Fund shall give the overwhelming benefit of any doubt to the participant's representation. Repayment shall be made after consultation with the participant in the currencies of other members that are convertible in fact, or made in gold, as determined by the Fund. If the Fund's holdings of currencies in which repayment should be made are not wholly adequate, individual participants shall be requested, and will be expected, to provide the necessary balance under their credit arrangements. If, notwithstanding the expectation that the participants will provide the necessary balance, they fail to do so, repayment shall be made to the extent necessary in the currency of the drawer for whose purchases the participant requesting repayment made transfers. For all of the purposes of this Paragraph 11, transfers under this Paragraph 11(f) shall be deemed to have been made at the same time and for the same purchases as the transfers by the participant obtaining repayment under this Paragraph 11(f).

(g) All repayments to a participant in a currency other than its own shall be guided, to the maximum extent practicable, by the present and prospective balance of payments and reserve positions of the members whose currencies are to be used in repayment.

(h) The Fund shall at no time reduce its holdings of a drawer's currency below an amount equal to the Fund's indebtedness to the participants resulting from transfers for the drawer's purchases.

(i) When any repayment is made to a participant, the amount that can be called for under its credit arrangement in accordance with this Decision shall be restored pro tanto but not beyond the amount of the credit arrangement. 


\section{THE GENERAL ARRANGEMENTS TO BORROW}

\section{Paragraph 12. Rates of Exchange}

(a) The value of any transfer shall be calculated as of the date of the transfer in terms of a stated number of fine ounces of gold or of the United States dollar of the weight and fineness in effect on July 1, 1944, and the Fund shall be obliged to repay an equivalent value.

(b) For all of the purposes of this Decision, the equivalent in currency of any number of fine ounces of gold or of the United States dollar of the weight and fineness in effect on July 1, 1944, or vice versa, shall be calculated at the rate of exchange at which the Fund holds such currency at the date as of which the calculation is made; provided however that the provisions of Decision No. 321(54/32) of the Executive Directors on Transactions and Computations Involving Fluctuating Currencies, as amended by Decision No. 1245-(61/45) and Decision No. 1283-(61/56), shall determine the rate of exchange for any currency to which that decision, as amended, has been applied.

\section{Paragraph 13. Transferability}

A participant may not transfer all or part of its claim to repayment under a credit arrangement except with the prior consent of the Fund and on such terms and conditions as the Fund may approve.

\section{Paragraph 14. Notices}

Notice to or by a participating member under this Decision shall be in writing or by cable and shall be given to or by the fiscal agency of the participating member designated in accordance with Article V, Section I of the Articles and Rule G-1 of the Rules and Regulations of the Fund. Notice to or by a participating institution shall be in writing or by cable and shall be given to or by the participating institution.

\section{Paragraph 15. Amendment}

This Decision may be amended during the period prescribed in Paragraph 19(a) only by a decision of the Fund and with the concurrence of all participants. Such concurrence shall not be necessary for the modification of the Decision on its renewal pursuant to Paragraph 19(b).

\section{Paragraph 16. Withdrawal of Adherence}

A participant may withdraw its adherence to this Decision in accordance with Paragraph 19(b) but may not withdraw within the period prescribed in Paragraph 19(a) except with the agreement of the Fund and all participants.

\section{Paragraph 17. Withdrawal from Membership}

If a participating member or a member whose institution is a participant 
withdraws from membership in the Fund, the participant's credit arrangement shall cease at the same time as the withdrawal takes effect. The Fund's indebtedness under the credit arrangement shall be treated as an amount due from the Fund for the purpose of Article XV, Section 3 and Schedule D of the Articles.

\section{Paragraph 18. Suspension of Exchange Transactions and Liquidation}

(a) The right of the Fund to make calls under Paragraph 7 and the obligation to make repayments under Paragraph 11 shall be suspended during any suspension of exchange transactions under Article XVI of the Articles.

(b) In the event of liquidation of the Fund, credit arrangements shall cease and the Fund's indebtedness shall constitute liabilities under Schedule E of the Articles. For the purpose of Paragraph 1(a) of Schedule E, the currency in which the liability of the Fund shall be payable shall be first the participant's currency and then the currency of the drawer for whose purchases transfers were made by the participant.

\section{Paragraph 19. Period and Renewal}

(a) This Decision shall continue in existence for four years from its effective date.

(b) This Decision may be renewed for such period or periods and with such modifications, subject to Paragraph 5, as the Fund may decide. The Fund shall adopt a decision on renewal and modification, if any, not later than twelve months before the end of the period prescribed in Paragraph 19(a). Any participant may advise the Fund not less than six months before the end of the period prescribed in Paragraph 19(a) that it will withdraw its adherence to the Decision as renewed. In the absence of such notice, a participant shall be deemed to continue to adhere to the Decision as renewed. Withdrawal of adherence in accordance with this Paragraph 19(b) by a participant, whether or not included in the Annex, shall not preclude its subsequent adherence in accordance with Paragraph 3(b).

(c) If this Decision is terminated or not renewed, Paragraphs 8 through 14, 17 and 18 (b) shall nevertheless continue to apply in connection with any indebtedness of the Fund under credit arrangements in existence at the date of the termination or expiration of the Decision until repayment is completed. If a participant withdraws its adherence to this Decision in accordance with Paragraph 16 or Paragraph 19(b), it shall cease to be a participant under the Decision, but Paragraphs 8 through 14, 17 and 18(b) of the Decision as of the date of the withdrawal shall nevertheless continue to apply to any indebtedness of the Fund under the former credit arrangement until repayment has been completed.

\section{Paragraph 20. Interpretation}

Any question of interpretation raised in connection with this Decision which does not fall within the purview of Article XVIII of the Articles shall be settled to the mutual satisfaction of the Fund, the participant raising the question, and all

\section{C)International Monetary Fund. Not for Redistribution}


other participants. For the purpose of this Paragraph 20 participants shall be deemed to include those former participants to which Paragraphs 8 through 14,17 and 18(b) continue to apply pursuant to Paragraph 19(c) to the extent that any such former participant is affected by a question of interpretation that is raised.

\section{ANNEX}

Participants and Amounts of Credit Arrangements

Units of Participant's

Currency

1. United States of America US\$

2. Deutsche Bundesbank DM

$2,000,000,000$

3. United Kingdom

$4,000,000,000$

$£$

$357,142,857$

4. France

$2,715,381,428$
$343,750,000,000$

5. Italy

NF

6. Japan

Lit

Yen

$90,000,000,000$

7. Canada

Can\$

$208,938,000$

8. Netherlands

$724,000,000$

9. Belgium

f.

BF

$7,500,000,000$

10. Sweden

SKr

$517,320,000$

Decision No. 1289-(62/1)

January 5, 1962

\section{The Baumgartner Letter}

Letter from Mr. Baumgartner, Minister of Finance, France, to Mr. Dillon. Secretary of the Treasury, United States

December 15, 1961

Dear Mr. Secretary:

The purpose of this letter is to set forth the understandings reached during the recent discussions in Paris with respect to the procedure to be followed by the Participating Countries and Institutions (hereinafter referred to as "the participants") in connection with borrowings by the International Monetary Fund of Supplementary Resources under credit arrangements which we expect will be established pursuant to a decision of the Executive Directors of the Fund. 
This procedure, which would apply after the entry into force of that decision with respect to the participants which adhere to it in accordance with their laws, and which would remain in effect during the period of the decision, is as follows:

A. A participating country which has need to draw currencies from the International Monetary Fund or to seek a stand-by agreement with the Fund in circumstances indicating that the Supplementary Resources might be used, shall consult with the Managing Director of the Fund first and then with the other participants.

B. If the Managing Director makes a proposal for Supplementary Resources to be lent to the Fund, the participants shall consult on this proposal and inform the Managing Director of the amounts of their currencies which they consider appropriate to lend to the Fund, taking into account the recommendations of the Managing Director and their present and prospective balance of payments and reserve positions. The participants shall aim at reaching unanimous agreement.

C. If it is not possible to reach unanimous agreement, the question whether the participants are prepared to facilitate, by lending their currencies, an exchange transaction or stand-by arrangement of the kind covered by the special borrowing arrangements and requiring the Fund's resources to be supplemented in the general order of magnitude proposed by the Managing Director, will be decided by a poll of the participants.

The prospective drawer will not be entitled to vote. A favorable decision shall require the following majorities of the participants which take part in the vote, it being understood that abstentions may be justified only for balance of payments reasons as stated in paragraph $D$ :

(1) A two-thirds majority of the number of participants voting; and

(2) a three-fifths majority of the weighted votes of the participants voting, weighted on the basis of the commitments to the Supplementary Resources.

D. If the decision in paragraph $\mathrm{C}$ is favorable, there shall be further consultations among the participants, and with the Managing Director, concerning the amounts of the currencies of the respective participants which will be loaned to the Fund in order to attain a total in the general order of magnitude agreed under paragraph $\mathrm{C}$. If during the consultations a participant gives notice that in its opinion, based on its present and prospective balance of payments and reserve position, calls should not be made on it, or that calls should be for a smaller amount than that proposed, the participants shall consult among themselves and with the Managing Director as to the additional amounts of their currencies which they could provide so as to reach the general order of magnitude agreed under paragraph $\mathrm{C}$.

E. When agreement is reached under paragraph D, each participant shall inform the Managing Director of the calls which it is prepared to meet under its credit arrangement with the Fund. 
F. If a participant which has loaned its currency to the Fund under its credit arrangement with the Fund subsequently requests a reversal of its loan which leads to further loans to the Fund by other participants, the participant seeking such reversal shall consult with the Managing Director and with the other participants.

For the purpose of the consultative procedures described above, participants will designate representatives who shall be empowered to act with respect to proposals for use of the Supplementary Resources.

It is understood that in the event of any proposals for calls under the credit arrangements or if other matters should arise under the Fund decision requiring consultations among the participants, a consultative meeting will be held among all the participants. The representative of France shall be responsible for calling the first meeting, and at that time the participants will determine who shall be the Chairman. The Managing Director of the Fund or his representative shall be invited to participate in these consultative meetings.

It is understood that in order to further the consultations envisaged, participants should, to the fullest extent practicable, use the facilities of the international organizations to which they belong in keeping each other informed of the developments in their balances of payments that could give rise to the use of the Supplementary Resources.

These consultative arrangements, undertaken in a spirit of international cooperation, are designed to insure the stability of the international payments system.

I shall appreciate a reply confirming that the foregoing represents the understandings which have been reached with respect to the procedure to be followed in connection with borrowings by the International Monetary Fund under the credit arrangements to which I have referred.

I am sending identical letters to the other participants-that is, Belgium, Canada, Germany, Italy, Japan, the Netherlands, Sweden, the United Kingdom. Attached is a verbatim text of this letter in English. The French and English texts and the replies of the participants in both languages shall be equally authentic. I shall notify all of the participants of the confirmations received in response to this letter.

\section{General Arrangements to Borrow: Revised Text}

\section{Preamble}

In order to enable the International Monetary Fund to fulfill more effectively its role in the international monetary system, the main industrial countries have agreed that they will, in a spirit of broad and willing cooperation, strengthen the Fund by general arrangements under which they will stand ready to make loans to the Fund up to specified amounts under Article VII, Section 1 of the Articles of Agreement when supplementary resources are needed to forestall or cope with an 
impairment of the international monetary system. In order to give effect to these intentions, the following terms and conditions are adopted under Article VII, Section 1 of the Articles of Agreement.

\section{Paragraph 1. Definitions}

As used in this Decision the term:

(i) "Articles" means the Articles of Agreement of the International Monetary Fund;

(ii) "credit arrangement" means an undertaking to lend to the Fund on the terms and conditions of this Decision;

(iii) "participant"' means a participating member or a participating institution;

(iv) "participating institution" means an official institution of a member that has entered into a credit arrangement with the Fund with the consent of the member;

(v) "participating member" means a member of the Fund that has entered into a credit arrangement with the Fund;

(vi) "amount of a credit arrangement" means the maximum amount expressed in special drawing rights that a participant undertakes to lend to the Fund under a credit arrangement;

(vii) "call" means a notice by the Fund to a participant to make a transfer under its credit arrangement to the Fund's account;

(viii) "borrowed currency" means currency transferred to the Fund's account under a credit arrangement;

(ix) "drawer" means a member that purchases borrowed currency from the Fund in an exchange transaction or in an exchange transaction under a stand-by or extended arrangement;

(x) "indebtedness" of the Fund means the amount it is committed to repay under a credit arrangement.

\section{Paragraph 2. Credit Arrangements}

A member or institution that adheres to this Decision undertakes to lend its currency to the Fund on the terms and conditions of this Decision up to the amount in special drawing rights set forth in the Annex to this Decision or established in accordance with Paragraph 3(b).

\section{Paragraph 3. Adherence}

(a) Any member or institution specified in the Annex may adhere to this Decision in accordance with Paragraph 3(c).

\section{CInternational Monetary Fund. Not for Redistribution}


(b) Any member or institution not specified in the Annex that wishes to become a participant may at any time, after consultation with the Fund, give notice of its willingness to adhere to this Decision, and, if the Fund shall so agree and no participant object, the member or institution may adhere in accordance with Paragraph 3(c). When giving notice of its willingness to adhere under this Paragraph 3(b) a member or institution shall specify the amount, expressed in terms of the special drawing right, of the credit arrangement which it is willing to enter into, provided that the amount shall not be less than the amount of the credit arrangement of the participant with the smallest credit arrangement.

(c) A member or institution shall adhere to this Decision by depositing with the Fund an instrument setting forth that it has adhered in accordance with its law and has taken all steps necessary to enable it to carry out the terms and conditions of this Decision. On the deposit of the instrument the member or institution shall be a participant as of the date of the deposit or of the effective date of this Decision, whichever shall be later.

\section{Paragraph 4. Entry into Force}

This Decision shall become effective when it has been adhered to by at least seven of the members or institutions included in the Annex with credit arrangements amounting in all to not less than the equivalent of five and one-half billion United States dollars of the weight and fineness in effect on July 1, 1944.

\section{Paragraph 5. Changes in Amounts of Credit Arrangements}

The amounts of participants' credit arrangements may be reviewed from time to time in the light of developing circumstances and changed with the agreement of the Fund and all participants.

\section{Paragraph 6. Initial Procedure}

When a participating member or a member whose institution is a participant approaches the Fund on an exchange transaction or stand-by or extended arrangement and the Managing Director, after consultation, considers that the exchange transaction or stand-by or extended arrangement is necessary in order to forestall or cope with an impairment of the international monetary system, and that the Fund's resources need to be supplemented for this purpose, he shall initiate the procedure for making calls under Paragraph 7.

\section{Paragraph 7. Calls}

(a) The Managing Director shall make a proposal for calls for an exchange transaction or for future calls for exchange transactions under a stand-by or extended arrangement only after consultation with Executive Directors and participants. A proposal shall become effective only if it is accepted by participants and the proposal is then approved by the Executive Board. Each 
participant shall notify the Fund of the acceptance of a proposal involving a call under its credit arrangement.

(b) The currencies and amounts to be called under one or more of the credit arrangements shall be based on the present and prospective balance of payments and reserve position of participating members or members whose institutions are participants and on the Fund's holdings of currencies.

(c) Unless otherwise provided in a proposal for future calls approved under Paragraph 7(a), purchases of borrowed currency under a stand-by arrangement shall be made in the currencies of participants in proportion to the amounts in the proposal.

(d) If a participant on which calls may be made pursuant to Paragraph 7(a) for a drawer's purchases under a stand-by or extended arrangement gives notice to the Fund that in the participant's opinion, based on the present and prospective balance of payments and reserve position, calls should no longer be made on the participant or that calls should be for a smaller amount, the Managing Director may propose to other participants that substitute amounts be made available under their credit arrangements, and this proposal shall be subject to the procedure of Paragraph 7(a). The proposal as originally approved under Paragraph 7(a) shall remain effective unless and until a proposal for substitute amounts is approved in accordance with Paragraph 7(a).

(e) When the Fund makes a call pursuant to this Paragraph 7, the participant shall promptly make the transfer in accordance with the call.

\section{Paragraph 8. Evidence of Indebtedness}

(a) The Fund shall issue to a participant, on its request, nonnegotiable instruments evidencing the Fund's indebtedness to the participant. The form of the instruments shall be agreed between the Fund and the participant.

(b) Upon repayment of the amount of any instrument issued under Paragraph 8(a) and all accrued interest, the instrument shall be returned to the Fund for cancellation. If less than the amount of any such instrument is repaid, the instrument shall be returned to the Fund and a new instrument for the remainder of the amount shall be substituted with the same maturity date as in the old instrument.

\section{Paragraph 9. Interest}

(a) The Fund shall pay interest on its indebtedness at a rate equal to the combined market interest rate computed by the Fund from time to time for the purpose of determining the rate at which it pays interest on holdings of special drawing rights. A change in the method of calculating the combined market interest rate shall apply only if the Fund and at least two thirds of the participants having three fifths of the total amount of the credit arrangements so agree; provided that if a participant so requests at the time this agreement is reached, the change shall not apply to the Fund's indebtedness to that participant outstanding at the date the change becomes effective. 


\section{THE GENERAL ARRANGEMENTS TO BORROW}

(b) Interest shall accrue daily and shall be paid as soon as possible after each July 31, October 31, January 31, and April 30.

(c) Interest due to a participant shall be paid, as determined by the Fund, in special drawing rights, or in the participant's currency, or in other currencies that are actually convertible.

\section{Paragraph 10. Use of Borrowed Currency}

The Fund's policies and practices under Article V, Sections 3 and 7 on the use of its general resources and stand-by and extended arrangements, including those relating to the period of use, shall apply to purchases of currency borrowed by the Fund. Nothing in this Decision shall affect the authority of the Fund with respect to requests for the use of its resources by individual members, and access to these resources by members shall be determined by the Fund's policies and practices, and shall not depend on whether the Fund can borrow under this Decision.

\section{Paragraph 11. Repayment by the Fund}

(a) Subject to the other provisions of this Paragraph 11, the Fund, five years after a transfer by a participant, shall repay the participant an amount equivalent to the transfer calculated in accordance with Paragraph 12. If the drawer for whose purchase participants make transfers is committed to repurchase at a fixed date earlier than five years after its purchase, the Fund shall repay the participants at that date. Repayment under this Paragraph 11(a) or under Paragraph 11(c) shall be, as determined by the Fund, in the participant's currency whenever feasible, or in special drawing rights, or, after consultation with the participant, in other currencies that are actually convertible. Repayments to a participant under Paragraph 11(b) and (e) shall be credited against transfers by the participant for a drawer's purchases in the order in which repayment must be made under this Paragraph 11(a).

(b) Before the date prescribed in Paragraph 11(a), the Fund, after consultation with a participant, may make repayment to the participant in part or in full. The Fund shall have the option to make repayment under this Paragraph 11(b) in the participant's currency, or in special drawing rights in an amount that does not increase the participant's holdings of special drawing rights above the limit under Article XIX, Section 4, of the Articles of Agreement unless the participant agrees to accept special drawing rights above that limit in such repayment, or, with the agreement of the participant, in other currencies that are actually convertible.

(c) Whenever a reduction in the Fund's holdings of a drawer's currency is attributed to a purchase of borrowed currency, the Fund shall promptly repay an equivalent amount. If the Fund is indebted to a participant as a result of transfers to finance a reserve tranche purchase by a drawer and the Fund's holdings of the drawer's currency that are not subject to repurchase are reduced as a result of net sales of that currency during a quarterly period covered by an operational budget, the Fund shall repay at the beginning of the next quarterly period an amount 
equivalent to that reduction, up to the amount of the indebtedness to the participant.

(d) Repayment under Paragraph 11(c) shall be made in proportion to the Fund's indebtedness to the participants that made transfers in respect of which repayment is being made.

(e) Before the date prescribed in Paragraph 11(a) a participant may give notice representing that there is a balance of payments need for repayment of part or all of the Fund's indebtedness and requesting such repayment. The Fund shall give the overwhelming benefit of any doubt to the participant's representation. Repayment shall be made after consultation with the participant in the currencies of other members that are actually convertible, or made in special drawing rights, as determined by the Fund. If the Fund's holdings of currencies in which repayment should be made are not wholly adequate, individual participants shall be requested, and will be expected, to provide the necessary balance under their credit arrangements. If, notwithstanding the expectation that the participants will provide the necessary balance, they fail to do so, repayment shall be made to the extent necessary in the currency of the drawer for whose purchases the participant requesting repayment made transfers. For all of the purposes of this Paragraph 11 transfers under this Paragraph 11(e) shall be deemed to have been made at the same time and for the same purchases as the transfers by the participant obtaining repayment under this Paragraph 11(e).

(f) All repayments to a participant in a currency other than its own shall be guided, to the maximum extent practicable, by the present and prospective balance of payments and reserve position of the members whose currencies are to be used in repayment.

(g) The Fund shall at no time reduce its holdings of a drawer's currency below an amount equal to the Fund's indebtedness to the participants resulting from transfers for the drawer's purchases.

(h) When any repayment is made to a participant, the amount that can be called for under its credit arrangement in accordance with this Decision shall be restored pro tanto.

(i) The Fund shall be deemed to have discharged its obligations to a participating institution to make repayment in accordance with the provisions of this Paragraph or to pay interest in accordance with the provisions of Paragraph 9 if the Fund transfers an equivalent amount in special drawing rights to the member in which the institution is established.

\section{Paragraph 12. Rates of Exchange}

(a) The value of any transfer shall be calculated as of the date of the dispatch of the instructions for the transfer. The calculation shall be made in terms of the special drawing right in accordance with Article XIX, Section 7(a) of the Articles, and the Fund shall be obliged to repay an equivalent value.

(b) For all of the purposes of this Decision, the value of a currency in terms of 


\section{THE GENERAL ARRANGEMENTS TO BORROW}

the special drawing right shall be calculated by the Fund in accordance with Rule O-2 of the Fund's Rules and Regulations.

\section{Paragraph 13. Transferability}

A participant may not transfer all or part of its claim to repayment under a credit arrangement except with the prior consent of the Fund and on such terms and conditions as the Fund may approve.

\section{Paragraph 14. Notices}

Notice to or by a participating member under this Decision shall be in writing or by rapid means of communication and shall be given to or by the fiscal agency of the participating member designated in accordance with Article V, Section 1 of the Articles and Rule G-1 of the Rules and Regulations of the Fund. Notice to or by a participating institution shall be in writing or by rapid means of communication and shall be given to or by the participating institution.

\section{Paragraph 15. Amendment}

This Decision may be amended during the period prescribed in Paragraph 19(a) only by a decision of the Fund and with the concurrence of all participants. Such concurrence shall not be necessary for the modification of the Decision on its renewal pursuant to Paragraph 19(b).

\section{Paragraph 16. Withdrawal of Adherence}

A participant may withdraw its adherence to this Decision in accordance with Paragraph 19(b) but may not withdraw within the period prescribed in Paragraph 19(a) except with the agreement of the Fund and all participants.

\section{Paragraph 17. Withdrawal from Membership}

If a participating member or a member whose institution is a participant withdraws from membership in the Fund, the participant's credit arrangement shall cease at the same time as the withdrawal takes effect. The Fund's indebtedness under the credit arrangement shall be treated as an amount due from the Fund for the purpose of Article XXVI, Section 3, and Schedule J of the Articles.

\section{Paragraph 18. Suspension of Exchange Transactions and Liquidation}

(a) The right of the Fund to make calls under Paragraph 7 and the obligation to make repayments under Paragraph 11 shall be suspended during any suspension of exchange transactions under Article XXVII of the Articles.

(b) In the event of liquidation of the Fund, credit arrangements shall cease and the Fund's indebtedness shall constitute liabilities under Schedule K of the 
Articles. For the purpose of Paragraph 1(a) of Schedule K, the currency in which the liability of the Fund shall be payable shall be first the participant's currency and then the currency of the drawer for whose purchases transfers were made by the participants.

\section{Paragraph 19. Period and Renewal}

(a) This Decision shall continue in existence for four years from its effective date. A new period of five years shall begin on the effective date of Decision No. 7337-(83/37), adopted February 24, 1983. References in Paragraph 19(b) to the period prescribed in Paragraph .19(a) shall refer to this new period and to any subsequent renewal periods that may be decided pursuant to Paragraph 19(b). When considering a renewal of this Decision for the period following the five-year period referred to in this Paragraph 19(a), the Fund and the participants shall review the functioning of this Decision, including the provisions of Paragraph 21.

(b) This Decision may be renewed for such period or periods and with such modifications, subject to Paragraph 5, as the Fund may decide. The Fund shall adopt a decision on renewal and modification, if any, not later than twelve months before the end of the period prescribed in Paragraph 19(a). Any participant may advise the Fund not less than six months before the end of the period prescribed in Paragraph 19(a) that it will withdraw its adherence to the Decision as renewed. In the absence of such notice, a participant shall be deemed to continue to adhere to the Decision as renewed. Withdrawal of adherence in accordance with this Paragraph 19(b) by a participant, whether or not included in the Annex, shall not preclude its subsequent adherence in accordance with Paragraph 3(b).

(c) If this Decision is terminated or not renewed, Paragraphs 8 through 14, 17 and 18 (b) shall nevertheless continue to apply in connection with any indebtedness of the Fund under credit arrangements in existence at the date of the termination or expiration of the Decision until repayment is completed. If a participant withdraws its adherence to this Decision in accordance with Paragraph 16 or Paragraph 19(b), it shall cease to be a participant under the Decision, but Paragraphs 8 through 14, 17 and 18(b) of the Decision as of the date of the withdrawal shall nevertheless continue to apply to any indebtedness of the Fund under the former credit arrangement until repayment has been completed.

\section{Paragraph 20. Interpretation}

Any question of interpretation raised in connection with this Decision which does not fall within the purview of Article XXIX of the Articles shall be settled to the mutual satisfaction of the Fund, the participant raising the question, and all other participants. For the purpose of this Paragraph 20 participants shall be deemed to include those former participants to which Paragraphs 8 through 14, 17 and 18(b) continue to apply pursuant to Paragraph 19(c) to the extent that any such former participant is affected by a question of interpretation that is raised. 


\section{Paragraph 21. Use of Credit Arrangements for Nonparticipants}

(a) The Fund may make calls in accordance with Paragraphs 6 and 7 for exchange transactions requested by members that are not participants if the exchange transactions are (i) transactions in the upper credit tranches, (ii) transactions under stand-by arrangements extending beyond the first credit tranche, (iii) transactions under extended arrangements, or (iv) transactions in the first credit tranche in conjunction with a stand-by or an extended arrangement. All the provisions of this Decision relating to calls shall apply, except as otherwise provided in Paragraph 21(b).

(b) The Managing Director may initiate the procedure for making calls under Paragraph 7 in connection with requests referred to in Paragraph 21(a) if, after consultation, he considers that the Fund faces an inadequacy of resources to meet actual and expected requests for financing that reflect the existence of an exceptional situation associated with balance of payments problems of members of a character or aggregate size that could threaten the stability of the international monetary system. In making proposals for calls pursuant to Paragraph 21(a) and (b), the Managing Director shall pay due regard to potential calls pursuant to other provisions of this Decision.

\section{Paragraph 22. Participation of the Swiss National Bank}

(a) Notwithstanding any other provision of this Decision, the Swiss National Bank (hereinafter called the Bank) may become a participant by adhering to this Decision in accordance with Paragraph 3(c) and accepting, by its adherence, a credit arrangement in an amount equivalent to one thousand and twenty million special drawing rights. Upon adherence, the Bank shall be deemed to be a participating institution, and all the provisions of this Decision relating to participating institutions shall apply in respect of the Bank, subject to, and as supplemented by, Paragraph 22(b), (c), (d), (e), and (f).

(b) Under its credit arrangement, the Bank undertakes to lend any currency, specified by the Managing Director after consultation with the Bank at the time of a call, that the Fund has determined to be a freely usable currency pursuant to Article $\mathrm{XXX}(f)$ of the Articles.

(c) In relation to the Bank, the references to the balance of payments and reserve position in Paragraph $7(\mathrm{~b})$ and (d), and Paragraph 11(e), shall be understood to refer to the position of the Swiss Confederation.

(d) In relation to the Bank, the references to a participant's currency in Paragraph 9(c), Paragraph 11(a) and (b), and Paragraph 18(b) shall be understood to refer to any currency, specified by the Managing Director after consultation with the Bank at the time of payment by the Fund, that the Fund has determined to be a freely usable currency pursuant to Article $\mathrm{XXX}(f)$ of the Articles.

(e) Payment of special drawing rights to the Bank pursuant to Paragraph 9(c) and Paragraph 11 shall be made only while the Bank is a prescribed holder pursuant to Article XVII of the Articles. 
(f) The Bank shall accept as binding a decision of the Fund on any question of interpretation raised in connection with this Decision which falls within the purview of Article XXIX of the Articles, to the same extent as that decision is binding on other participants.

\section{Paragraph 23. Associated Borrowing Arrangements}

(a) A borrowing arrangement between the Fund and a member that is not a participant, or an official institution of such a member, under which the member or the official institution undertakes to make loans to the Fund for the same purposes as, and on terms comparable to, those made by participants under this Decision, may, with the concurrence of all participants, authorize the Fund to make calls on participants in accordance with Paragraphs 6 and 7 for exchange transactions with that member, or to make requests under Paragraph 11(e) in connection with an early repayment of a claim under the borrowing arrangement, or both. For the purposes of this Decision such calls or requests shall be treated as if they were calls or requests in respect of a participant.

(b) Nothing in this Decision shall preclude the Fund from entering into any other types of borrowing arrangements, including an arrangement between the Fund and a lender, involving an association with participants, that does not contain the authorizations referred to in Paragraph 23(a).

\section{ANNEX}

Participants and Amounts of Credit Arrangements

I. Prior to the Effective Date of Decision No. 7337-(83/37)

\begin{tabular}{llr} 
& & \multicolumn{1}{c}{$\begin{array}{c}\text { Amount } \\
\text { in Units of } \\
\text { Participant's } \\
\text { Currency }\end{array}$} \\
1. United States of America & US\$ & $2,000,000,000$ \\
2. Deutsche Bundesbank & DM & $4,000,000,000$ \\
3. United Kingdom & $f$ & $357,142,857$ \\
4. France & F & $2,715,381,428$ \\
5. Italy & Lit & $343,750,000,000$ \\
6. Japan & Yen & $340,000,000,000$ \\
7. Canada & Can\$ & $216,216,000$ \\
8. Netherlands & f. & $724,000,000$ \\
9. Belgium & BF & $7,500,000,000$ \\
10. Sveriges Riksbank & SKr & $517,320,000$
\end{tabular}


II. From the Effective Date of Decision No. 7337-(83/37)

\begin{tabular}{lr} 
& \multicolumn{1}{c}{$\begin{array}{c}\text { Amount } \\
\text { in Special } \\
\text { Drawing Rights }\end{array}$} \\
1. United States of America & $4,250,000,000$ \\
2. Deutsche Bundesbank & $2,380,000,000$ \\
3. Japan & $2,125,000,000$ \\
4. France & $1,700,000,000$ \\
5. United Kingdom & $1,700,000,000$ \\
6. Italy & $1,105,000,000$ \\
7. Canada & $892,500,000$ \\
8. Netherlands & $850,000,000$ \\
9. Belgium & $595,000,000$ \\
10. Sveriges Riksbank & $382,500,000$ \\
11. Swiss National Bank* & $1,020,000,000$ \\
\cline { 2 - 2 } & $17,000,000,000$
\end{tabular}

*With effect from the date on which the Swiss National Bank adheres to this Decision in accordance with Paragraph 22.

Decision No. 7337-(83/37)

February 24, 1983

\section{Borrowing Arrangement with Saudi Arabia in Association with the General Arrangements to Borrow}

Pursuant to Article VII, Section 1 of the Articles of Agreement, the Managing Director is authorized to send to the Minister of Finance of Saudi Arabia a letter proposing a borrowing agreement with Saudi Arabia, as set forth in the attachment. When a reply is received from the Minister accepting the proposal, the Managing Director's letter and the reply shall constitute an agreement between Saudi Arabia and the Fund, which shall enter into force on the date on which the revised and enlarged General Arrangements to Borrow authorized by Decision No. 7337-(83/37) become effective.

Decision No. 7403-(83/73)

May 20, 1983

\section{Attachment}

Your Excellency:

I refer to Decision No. 7337-(83/37) of the Executive Board of the International Monetary Fund (the Fund), providing for a revision and enlargement of the General Arrangements to Borrow (the GAB), and to the desire of Saudi Arabia to 
strengthen the Fund by providing supplementary resources, in association with and for the same purposes as the GAB. Accordingly, pursuant to Article VII of the Articles of Agreement of the Fund (the Articles) and Executive Board Decision No. 7403-(83/73), adopted May 20, 1983, I have been authorized to propose on behalf of the Fund that Saudi Arabia enter into an Agreement with the Fund as set forth below:

\section{Paragraph 1. The Credit Arrangement}

During the period specified in Paragraph 2 and any renewal thereof, Saudi Arabia will stand ready to lend Saudi riyals to the Fund up to a maximum amount equivalent to one thousand five hundred million SDRs (SDR 1,500,000,000), on the terms and conditions set forth in this Agreement, to assist the Fund in the financing of purchases by members for the same purposes and in the same circumstances as are prescribed in the GAB. This amount may be changed by agreement between Saudi Arabia and the Fund.

\section{Paragraph 2. Period of Credit Arrangement and Renewal}

(a) Amounts of resources may be called by the Fund hereunder during a period of five years from the date this Agreement enters into force, unless the Fund's right to make calls is terminated earlier in accordance with this Agreement.

(b) When a renewal of the GAB Decision is under consideration, the Fund and Saudi Arabia shall consult regarding the renewal of the credit arrangement under this Agreement or the conclusion of such other credit arrangement as may be found appropriate at that time.

(c) Notwithstanding the termination of the credit arrangement under this Agreement, the provisions of Paragraphs 4 through 13 shall continue to apply until all the obligations of the Fund under this Agreement have been discharged.

\section{Paragraph 3. Calls}

(a) Calls may be made only pursuant to a proposal of the Managing Director that has become effective in accordance with (d) below.

(b) The Managing Director may make a proposal for calls for purchases, including future calls for purchases under stand-by or extended arrangements, (i) if he considers that a proposal for calls or future calls for the same purchases could be made under the GAB and (ii) after consultations with Saudi Arabia at the same time and in the same manner as he consults GAB participants.

(c) In deciding whether to make a proposal and the amount to be called thereunder, the Managing Director shall take into account the present and prospective balance of payments and reserve position of Saudi Arabia and the Fund's holdings of Saudi riyals.

(d) A proposal for calls shall become effective only when Saudi Arabia has notified the Fund that it accepts the proposal and the proposal has been approved

\section{CInternational Monetary Fund. Not for Redistribution}


by the Executive Board of the Fund. Calls shall be made as and when amounts of Saudi riyals are needed by the Fund to finance purchases covered by the proposal.

(e) When the Fund makes a call, Saudi Arabia shall transfer to the account of the Fund, free of any charge or commission, an amount of Saudi riyals equivalent to the amount of the call. The transfer shall be made on the date specified in the call. Saudi Arabia shall exchange the riyals for a freely usable currency of its choice in accordance with Article V, Section 3 of the Articles.

(f) If Saudi Arabia represents to the Fund that, in view of the present and prospective balance of payments and reserve position of Saudi Arabia, future calls under a proposal that has become effective as provided in (d) above should no longer be made or be made for a smaller amount and the Fund, after giving the overwhelming benefit of any doubt to the representation, determines that it is justified, the Fund shall comply with Saudi Arabia's representation.

\section{Paragraph 4. Evidence of Indebtedness}

The Fund shall issue to Saudi Arabia, at its request, a nonnegotiable instrument or instruments in a form to be agreed with Saudi Arabia, evidencing the Fund's outstanding indebtedness to Saudi Arabia under this Agreement. Upon repayment of an amount of indebtedness evidenced by an instrument and all accrued interest thereon, the instrument shall be returned to the Fund for cancellation, and if any balance of the indebtedness remains outstanding, the Fund shall issue a new instrument for the remainder of the amount, with the same maturity date.

\section{Paragraph 5. Interest}

(a) The Fund shall pay interest on its outstanding indebtedness at a rate equal to the combined market interest rate computed by the Fund from time to time under its Rules and Regulations for the purpose of determining the rate at which it pays interest on holdings of SDRs. If the Fund changes the method of computing the combined market interest rate, the new method will apply to amounts borrowed hereunder only if it is applied to borrowing by the Fund under the GAB, and Saudi Arabia agrees.

(b) Interest shall accrue daily and shall be paid as soon as possible after each July 31 , October 31 , January 31 , and April 30.

\section{Paragraph 6. Repayments by the Fund}

(a) Subject to the other provisions of this Agreement, the Fund shall repay an amount equal to each amount transferred by Saudi Arabia hereunder five years after the date the transfer was made. To the extent the member whose purchase the amount was used to finance is committed to repurchase by installments on fixed dates falling earlier than five years after that date, the Fund shall repay the amount in corresponding installments on those fixed dates.

(b) Whenever a reduction in the Fund's holdings of currency of a purchasing member is attributed to a purchase financed with an amount transferred by Saudi 
Arabia hereunder, the Fund shall promptly make a corresponding repayment to Saudi Arabia. If the amount was used to finance a reserve tranche purchase, and the Fund's holdings of the purchasing member's currency not subject to repurchase are reduced as a result of net sales of the currency during a quarterly period covered by an operational budget, the Fund shall make a corresponding repayment to Saudi Arabia at the beginning of the next quarterly period. The amount repaid under this subparagraph (b) shall bear the same proportion to the amount of the reduction as the amount transferred under this Agreement bears to the amount of the purchase.

(c) Before the date repayment is due under (a) or (b) above, the Fund, after consultation with Saudi Arabia, may repay all or part of its outstanding indebtedness hereunder.

(d) If Saudi Arabia represents to the Fund that it has a balance of payments need for repayment before the due date of all or part of such outstanding indebtedness and requests such repayment, and the Fund after giving Saudi Arabia's representation the overwhelming benefit of any doubt determines that there is such a need, the Fund shall make early repayment as requested by Saudi Arabia.

(e) Amounts repaid under (c) and (d) shall be credited against outstanding indebtedness in the order in which such indebtedness would fall due under (a) above.

(f) The Fund shall at no time reduce its holdings of the currency of a member whose purchases were financed by borrowing hereunder below an amount equal to the outstanding amount of such borrowing plus any outstanding amount borrowed under the GAB to finance purchases by the same member.

(g) When any repayment is made to Saudi Arabia, the amount that the Fund may call for under the credit arrangement shall be restored pro tanto.

\section{Paragraph 7. Media of Payment}

(a) Payments of interest and repayments of principal shall be made, as determined by the Fund after consultation with Saudi Arabia, in Saudi riyals, in SDRs, or in currencies that are actually convertible; provided that (i) unless Saudi Arabia agrees, SDRs shall not be used in early repayment under Paragraph 6(c) if the effect would be to increase Saudi Arabia's holdings of SDRs above the limit specified in Article XIX, Section 4 of the Articles, and (ii) Saudi riyals shall not be used in early repayment on balance of payments grounds under Paragraph 6(d).

(b) Currencies other than Saudi riyals to be used in payment of interest and repayment of principal shall be selected by the Fund from those that can be used in net sales under the operational budget of the Fund in effect at the time the payment is made.

\section{Paragraph 8. Rates of Exchange}

All amounts under this Agreement shall be denominated in SDRs, as valued by the Fund from time to time. The value in terms of SDRs of Saudi riyals to be 
transferred by Saudi Arabia to the Fund and of payments to be made by the Fund to Saudi Arabia in currencies shall be determined in accordance with Rule O-2 of the Rules and Regulations of the Fund.

\section{Paragraph 9. Transferability}

Saudi Arabia may transfer all or part of its claims under this Agreement only with the prior consent of the Fund and on such terms and conditions as the Fund may approve.

\section{Paragraph 10. Withdrawal from Membership}

If Saudi Arabia withdraws from membership in the Fund, no further calls shall be made hereunder. The Fund's outstanding indebtedness hereunder shall be treated as an amount due from the Fund for the purpose of Article XXVI, Section 3, and Schedule $\mathrm{J}$ of the Articles.

\section{Paragraph 11. Suspension of Exchange Transactions and Liquidation}

(a) The right of the Fund to make calls and its obligation to make repayment hereunder shall be suspended during any suspension of exchange transactions under Article XXVII of the Articles.

(b) In the event of liquidation of the Fund, no further calls shall be made by the Fund hereunder. The Fund's outstanding indebtedness shall constitute a liability under Schedule K of the Articles. For the purpose of Paragraph 1(a) of Schedule $\mathrm{K}$, the currency in which each amount of the Fund's indebtedness is payable shall be first Saudi riyals and then any currency that is actually convertible.

\section{Paragraph 12. Amendments}

(a) This Agreement may be amended at any time, by agreement between Saudi Arabia and the Fund.

(b) If the revised and enlarged GAB is modified while this Agreement is in effect, Saudi Arabia and the Fund will consult with each other with a view to determining whether consequential modifications should be made in the provisions of this Agreement.

(c) If, after consultations with the Fund and the GAB participants, Saudi Arabia proposes that the credit arrangement under this Agreement be converted into or replaced by an arrangement of the type referred to in Paragraph 23(a) or Paragraph 3(b) of the revised GAB Decision, as the case may be, the Fund will consider the steps to be taken, subject to the concurrence of the GAB participants as necessary, to effect such conversion or replacement.

\section{Paragraph 13. Interpretation; Settlement of Disputes}

Any question of interpretation arising in connection with this Agreement that does not fall within the purview of Article XXIX of the Articles, any dispute 
arising hereunder, shall be settled to the mutual satisfaction of Saudi Arabia and the Fund.

If the foregoing proposal is acceptable to Saudi Arabia, this communication and your reply indicating Saudi Arabia's acceptance shall constitute an Agreement between Saudi Arabia and the Fund, which shall enter into force on the date on which the revised and enlarged GAB authorized by Decision No. 7337-(83/37) of the Executive Board of the Fund becomes effective.

Very truly yours, /s/

J. de Larosière

V. Distribution of Calls on the General Arrangements to Borrow TABLE 5. BorRowing By THE FUnd UNDER THE GAB, $1964-70$ (In millions of U.S. dollars)

\begin{tabular}{|c|c|c|c|c|c|c|c|}
\hline \multirow[b]{4}{*}{ Participant } & \multicolumn{7}{|c|}{ Beneficiary } \\
\hline & \multirow{2}{*}{\multicolumn{3}{|c|}{ United Kingdom }} & \multirow{3}{*}{$\begin{array}{c}\text { France } \\
\text { June } \\
1968\end{array}$} & \multirow{3}{*}{$\begin{array}{c}\text { United } \\
\text { Kingdom } \\
\text { June } \\
1969\end{array}$} & \multicolumn{2}{|c|}{$\begin{array}{c}\text { France } \\
\text { Sept. } 1969\end{array}$} \\
\hline & & & & & & \multirow[b]{2}{*}{$\begin{array}{l}\text { Amount of } \\
\text { Activation }\end{array}$} & \multirow{2}{*}{$\begin{array}{l}\text { Amoun } \\
\text { Actually } \\
\text { Drawn }\end{array}$} \\
\hline & $\begin{array}{l}\text { Dec. } \\
1964\end{array}$ & $\begin{array}{l}\text { May } \\
1965\end{array}$ & $\begin{array}{l}\text { Nov. } \\
1967\end{array}$ & & & & \\
\hline Belgium & 30 & 37.5 & 55 & 15 & - & - & - \\
\hline Canada & 15 & 35.0 & - & - & 40 & 50 & 50 \\
\hline France & 100 & 140.0 & - & - & - & - & 一 \\
\hline \multicolumn{8}{|l|}{ Deutsche } \\
\hline Bundesbank & 180 & 167.5 & 226 & 140 & 90 & 185 & $94^{\prime}$ \\
\hline Italy & 5 & 65.0 & 125 & 60 & 20 & 60 & 60 \\
\hline Japan & 20 & 25.0 & - & - & 40 & 65 & 65 \\
\hline Netherlands & 40 & 37.5 & 40 & 35 & 10 & 15 & 15 \\
\hline \multicolumn{8}{|l|}{ Sveriges } \\
\hline Riksbank & 15 & 17.5 & 30 & 15 & - & - & - \\
\hline \multicolumn{8}{|l|}{ United } \\
\hline Kingdom & - & - & - & - & - & - & - \\
\hline \multicolumn{8}{|l|}{ United } \\
\hline States & - & - & - & - & - & - & - \\
\hline Total & 405 & 525.0 & 476 & 265 & 200 & 375 & 284 \\
\hline
\end{tabular}

${ }^{1}$ The amount proposed for the Deutsche Bundesbank was reduced after the activation because of a change in the Federal Republic of Germany's balance of payments position. 
(In millions of SDRs)

\begin{tabular}{|c|c|c|c|c|c|}
\hline \multirow[b]{3}{*}{ Participant } & \multicolumn{5}{|c|}{ Beneficiary } \\
\hline & \multicolumn{2}{|c|}{$\begin{array}{c}\text { United Kingdom } \\
\text { January } 1977\end{array}$} & \multicolumn{2}{|c|}{$\begin{array}{c}\text { Italy } \\
\text { May } 1977\end{array}$} & \multirow{2}{*}{$\begin{array}{c}\text { United States } \\
\text { November } 1978 \\
\text { Amount } \\
\text { Actually } \\
\text { Drawn }\end{array}$} \\
\hline & $\begin{array}{l}\text { Amount of } \\
\text { Activation }\end{array}$ & $\begin{array}{l}\text { Amount } \\
\text { Actually } \\
\text { Drawn }\end{array}$ & $\begin{array}{l}\text { Amount of } \\
\text { Activation }\end{array}$ & $\begin{array}{c}\text { Amount } \\
\text { Actually } \\
\text { Drawn }\end{array}$ & \\
\hline Belgium & 45 & 26.2 & 16 & 3.9 & - \\
\hline Canada & 55 & 32.2 & 16 & 3.9 & - \\
\hline France & 50 & 29.2 & 35 & 8.6 & - \\
\hline \multicolumn{6}{|l|}{ Deutsche } \\
\hline Bundesbank & 785 & 458.1 & 82 & 20.2 & 582.9 \\
\hline Italy & - & - & - & - & - \\
\hline Japan & 555 & 323.8 & 62 & 15.2 & 194.3 \\
\hline Netherlands & 105 & 61.4 & 20 & 4.9 & - \\
\hline \multicolumn{6}{|l|}{ Sveriges } \\
\hline Riksbank & 20 & 11.7 & 8 & 2.0 & - \\
\hline \multicolumn{6}{|l|}{ United } \\
\hline Kingdom & - & - & - & - & - \\
\hline \multicolumn{6}{|l|}{ United } \\
\hline States & 945 & 551.4 & 98 & 24.0 & - \\
\hline GAB total & 2,560 & $1,493.5$ & 337 & 82.5 & 777.3 \\
\hline \multicolumn{6}{|l|}{ Swiss National } \\
\hline Bank & 300 & 146.5 & 37.5 & 7.5 & - \\
\hline Overall total & $\overline{2,860}$ & $\overline{1,640.0}$ & 374.5 & 90.0 & 777.3 \\
\hline
\end{tabular}

CInternational Monetary Fund. Not for Redistribution 


\section{SELECTED BIBLIOGRAPHY}

Ainley, E.M., The IMF: Past, Present and Future (Bangor: University of Wales Press, 1979).

de Vries, Margaret Garritsen, The International Monetary Fund, 1966-1971: The System Under Stress (Washington: International Monetary Fund, 1976), 2 vols. , The International Monetary Fund, 1972-1978: International Monetary

Cooperation on Trial (Washington: International Monetary Fund, forthcoming), 3 vols.

Gold, Joseph, The Fund's Concept of Convertibility, IMF Pamphlet Series, No. 14 (Washington: International Monetary Fund, 1971).

, International Capital Movements Under the Law of the International

Monetary Fund, IMF Pamphlet Series, No. 21 (Washington: International Monetary Fund, 1977).

Legal and Institutional Aspects of the International Monetary System:

Selected Essays (Washington: International Monetary Fund, 1979).

, Legal and Institutional Aspects of the International Monetary System:

Selected Essays, Vol. 2 (Washington: International Monetary Fund, 1984).

Halm, George N., The International Monetary Fund and Flexibility of Exchange

Rates, Essays in International Finance, No. 83 (Princeton, New Jersey:

International Finance Section, Princeton University, March 1971).

Horsefield, J.K., and others, The International Monetary Fund, 1945-1965:

Twenty Years of International Monetary Cooperation (Washington: International Monetary Fund, 1969), 3 vols.

International Monetary Fund, Annual Report of the Executive Board (Washington), various issues.

, Summary Proceedings of the Annual Meeting of the Board of Governors

(Washington), various issues.

Jacobsson, Erin E., A Life for Sound Money: Per Jacobsson: His Biography (Oxford, England: Clarendon Press, 1979).

Selected Decisions of the International Monetary Fund and Selected Documents (Washington), various issues.

United States, National Advisory Council on International Monetary and Financial Policies, Annual Report to the President and to the Congress for Fiscal Year 1982 (Washington: Government Printing Office, 1983).

Williams, David, "Increasing the Resources of the Fund: Borrowing," Finance \&

Development (Washington), Vol. 13 (September 1976), pp. 19-23

Williamson, John, The Failure of World Monetary Reform, 1971-74 (Sunburyon-Thames, England: Nelson, 1977). 
(Continued from inside front cover)

24. The Rise in Protectionism, by Trade and Payments Division. 1978.

25. The Second Amendment of the Fund's Articles of Agreement, by Joseph Gold. 1978.

26. SDRs, Gold, and Currencies: Third Survey of New Legal Developments, by Joseph Gold. 1979. Concluding section also in German.

27. Financial Assistance by the International Monetary Fund: Law and Practice, by Joseph Gold. First edition. 1979. In English only. Second edition. 1980.

28. Thoughts on an International Monetary Fund Based Fully on the SDR, by J. J. Polak. 1979.

29. Macroeconomic Accounts: An Overview, by Poul Høst-Madsen. 1979.

30. Technical Assistance Services of the International Monetary Fund. 1979

31. Conditionality, by Joseph Gold. 1979.

32. The Rule of Law in the International Monetary Fund, by Joseph Gold. 1980.

33. SDRs, Currencies, and Gold: Fourth Survey of New Legal Developments, by Joseph Gold. 1980.

34. Compensatory Financing Facility, by Louis M. Goreux. 1980.

35. The Legal Character of the Fund's Stand-By Arrangements and Why It Matters, by Joseph Gold. 1980.

36. SDRs, Currencies, and Gold: Fifth Survey of New Legal Developments, by Joseph Gold. 1981.

37. The International Monetary Fund: Its Evolution, Organization, and Activities. First edition, 1981. Fourth edition, 1984.

38. Fund Conditionality: Evolution of Principles and Practices, by Manuel Guitián. 1981.

39. Order in International Finance, the Promotion of IMF Stand-By Arrangements, and the Drafting of Private Loan Agreements, by Joseph Gold. 1982.

40. SDRs, Currencies, and Gold: Sixth Survey of New Legal Developments, by Joseph Gold. 1983. In English. French and Spanish in preparation.

41. The General Arrangements to Borrow, by Michael Ainley. 1984. In English. French and Spanish in preparation.

42. The International Monetary Fund: Its Financial Organization and Activities, by Anand G. Chandavarkar. 1984. In English. French and Spanish in preparation.

43. The Technical Assistance and Training Services of the International Monetary Fund. In English. French and Spanish in preparation.

*Out of print. Photographic or microfilm copies of all English editions, including numbers that are out of print, may be purchased direct from University Microfilms International, 300 North Zeeb Road. Ann Arbor, Michigan 48106, U.S.A., or, for those living outside the Western Hemisphere, from University Microfilms Limited, 30/32 Mortimer St., London. WIN 7RA, England.

Copies (unless out of print) may be requested from:

External Relations Department. Attention: Publications

International Monetary Fund, Washington, D.C. 20431, U.S.A.

Telephone number: 202 623-7430

Cable address: Interfund

\section{CInternational Monetary Fund. Not for Redistribution}

